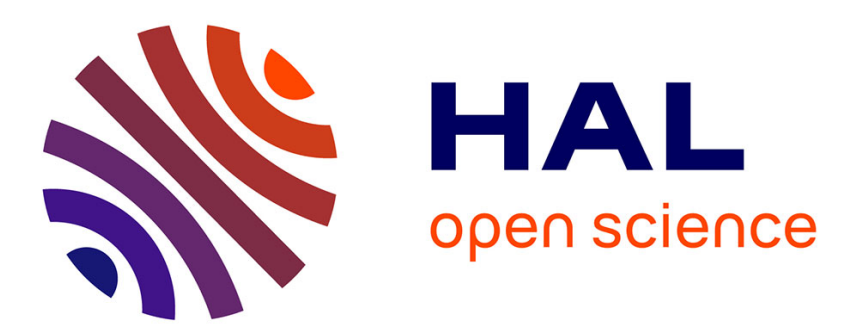

\title{
Nanoscale chemical zoning of chlorite and implications for low-temperature thermometry: Application to the Glarus Alps (Switzerland)
}

\author{
Franck Bourdelle, Olivier Beyssac, Teddy Parra, Christian Chopin
}

\section{- To cite this version:}

Franck Bourdelle, Olivier Beyssac, Teddy Parra, Christian Chopin. Nanoscale chemical zoning of chlorite and implications for low-temperature thermometry: Application to the Glarus Alps (Switzerland). Lithos, 2018, 314-315, pp.551-561. 10.1016/j.lithos.2018.06.030 . hal-02270199

\section{HAL Id: hal-02270199 \\ https://hal.sorbonne-universite.fr/hal-02270199}

Submitted on 23 Aug 2019

HAL is a multi-disciplinary open access archive for the deposit and dissemination of scientific research documents, whether they are published or not. The documents may come from teaching and research institutions in France or abroad, or from public or private research centers.
L'archive ouverte pluridisciplinaire HAL, est destinée au dépôt et à la diffusion de documents scientifiques de niveau recherche, publiés ou non, émanant des établissements d'enseignement et de recherche français ou étrangers, des laboratoires publics ou privés. 
1 Nanoscale chemical zoning of chlorite and implications for low-temperature

2 thermometry: application to the Glarus Alps (Switzerland)

3

4 Authors: Franck Bourdelle ${ }^{\mathrm{a}, *}$, Olivier Beyssac ${ }^{\mathrm{b}}$, Teddy Parra $^{\mathrm{c}}$, Christian Chopin $^{\mathrm{d}}$

5

6 a Laboratoire Génie Civil et géo-Environnement (LGCgE), Université de Lille, Cité

7 Scientifique, SN5, 59655 Villeneuve-d'Ascq cedex, France

8 b Institut de Minéralogie, de Physique des matériaux et de Cosmochimie (IMPMC), CNRS -

9 UMR 7590, Sorbonne Université-MNHN-IRD, 4 place Jussieu, 75005 Paris, France

$10{ }^{\mathrm{c}}$ Lycée Elisa Lemonnier, 20 avenue Armand Rousseau, 75012 Paris cedex, France

11 d Laboratoire de Géologie, Ecole Normale Supérieure (ENS), CNRS - UMR 8538, PSL

12 Research University, 24 rue Lhomond, 75231 Paris cedex 5, France

13

$14 *$ Corresponding author:

15 Franck Bourdelle

16 Present mailing address: Laboratoire Génie Civil et géo-Environnement (LGCgE) -

17 Département des Sciences de la Terre, Université de Lille, Cité Scientifique, Bâtiment SN5,

1859655 Villeneuve d'Ascq Cedex, France.

19 E-mail address: franck.bourdelle@ univ-lille.fr

20 Phone number: + $33(0) 320434113$

$21 \quad$ Fax number: + $33(0) 320336333$ 


\section{Abstract}

A combination of adapted chlorite thermometry and high-spatial-resolution analytical techniques (TEM-EDX/FIB) shows that the low-grade metamorphic chlorites of the Glarus Alps, Central Alps (Switzerland), do not record the peak metamorphic conditions as commonly assumed in previous studies of this reference area for low-grade metamorphism.

Chlorites have rather recorded several stages of the retrograde path, through an intracrystalline nanometric-scale compositional zoning. The consistency of the nanoscale zoning patterns observed both within sample and along the transect suggests that local equilibrium was achieved at this scale and maintained during growth or re-equilibration. Applying recent thermobarometers, we highlight that chlorites recorded a distinct behaviour between the northern and southern part of the studied transect: the south of the Glarus area displays a regular $P-T$ exhumation path, from $3.0 \pm 0.2 \mathrm{kbar}$ and $310 \pm 20{ }^{\circ} \mathrm{C}$ for maximum $P$ $T$ (estimated with conventional thermometers), to $\sim 0.8 \mathrm{kbar}$ and $\sim 220^{\circ} \mathrm{C}$ according to chlorite crystal-core analysis, and to $\sim 0.3 \mathrm{kbar}$ and $\sim 190{ }^{\circ} \mathrm{C}$ according to chlorite crystal-rim analysis.

On the contrary, the north of the Glarus area shows an apparent break in the exhumation, with $P$ estimates from chlorite crystal rims $(\sim 1.3 \mathrm{kbar})$ higher than from chlorite crystal cores $(\sim 0.8$ kbar). Even if the absolute pressure values are fraught with large uncertainty, their contrasting core/rim pattern is not model dependent. We try to correlate these new thermobarometric results with independent data to refine the exhumation scenario of the North-Helvetic flyschs, confirming differential uplift along the transect. This reappraisal of Glarus chlorite thermometry demonstrates that an adapted thermometry/analysis protocol opens new prospects for investigating the evolution of low-grade metamorphic terranes.

Key words: chlorite, thermometry, Glarus, low-grade metamorphism 


\section{Introduction}

Quantifying the thermal history of low-grade metamorphic rocks, i.e. in the temperature $(T)$ range below $350{ }^{\circ} \mathrm{C}$, is challenging because kinetics are much more sluggish than at higher metamorphic grade. For instance, the short diffusion lengths require the use of advanced in situ analytical approaches to obtain accurate crystallochemical information in chemically heterogeneous crystals down to the nanoscale. A first necessity is therefore to choose the appropriate thermometer for the targeted rocks among the multiple tools available, e.g. composition of phyllosilicates, oxygen isotope partitioning, structural and/or chemical evolution of carbonaceous material, or thermochronologic methods.

In this respect, since the 1980s, the compositional change of chlorite in low- $T$ settings has been considered as a good proxy for the temperature of formation (e.g., Cathelineau and Nieva, 1985). As a consequence, many chlorite thermometers have been developed, first via empirical equations linking chlorite $\mathrm{Al}^{\mathrm{IV}}$ content and temperature, with a correction based on the Fe/Mg ratio (Kranidiotis and McLean, 1987; Jowett, 1991; Zang and Fyfe, 1995; Xie et al., 1997) or without such (Cathelineau, 1988; Hillier and Velde, 1991). In the absence of constrained thermodynamic models - able to take into account all the substitutions occurring in chlorites - these empirical thermometers were widely used during the 1990 s to estimate $T$ conditions in diagenetic and low-grade metamorphic environments, like the Glarus Alps complex in Switzerland (e.g., Rahn et al., 1994, 1995). In reality, each of these empirical thermometers was calibrated for a particular context with specific applicability conditions (as reviewed by Bourdelle and Cathelineau, 2015), and their systematic application without due consideration of these conditions failed or led to erroneous geological interpretations in many instances, as shown by de Caritat et al. (1993) for instance.

Since the 2000s, chlorite thermometry is reappraised and several thermodynamic (Vidal et al., 2001, 2005, 2006; Lanari et al., 2014) or semi-empirical models (Inoue et al., 2009; Bourdelle et al., 2013a; Lanari et al., 2014) have been published, with the goal to improve the theoretical background beyond these methods and their reliability. These models 
consider the chlorite + quartz equilibrium and are based on a combination of chlorite endmembers. They take into account the Tschermak $\left(\mathrm{Al}^{\mathrm{IV}} \mathrm{Al}^{\mathrm{VI}}=\mathrm{Si}\left[\mathrm{Mg}, \mathrm{Fe}^{2+}\right]\right)$, the ferromagnesian $\left(\mathrm{Fe}^{2+}=\mathrm{Mg}\right)$ and the di/trioctahedral $\left(3\left[\mathrm{Mg}, \mathrm{Fe}^{2+}\right]=\square+2 \mathrm{Al}^{\mathrm{VI}}\right.$; where represents an octahedral vacancy) substitutions occurring in chlorites. Each of these thermometers has its own formulation, assumptions (like $\mathrm{Fe}^{3+}$ consideration, non-ideality, compositional field, etc) and applicability field (low $T$ and $P$, high $T$ and $P$ ). When correctly applied, they have shown their efficiency in various geological contexts (see Inoue et al., 2010; Kameda et al., 2011, 2012; Ganne et al., 2012; Trincal et al., 2015; Scheffer et al., 2016; Mamane Mamadou et al., 2016; Chinchilla et al., 2016) as well as in experimental cases (e.g. Mosser-Ruck et al., 2016).

Another possible issue at low $T$ is that diffusion is sluggish and therefore the composition of chlorites may be modified only over very short distances, i.e. at the nanoscale, during advanced diagenesis and/or metamorphic evolution. Fortunately, several high-spatialresolution analytical techniques have become more accessible for petrology, such as Focused Ion Beam (FIB), Transmission Electron Microscopy (TEM) coupled with EDX probe (Energy Dispersive X-ray spectroscopy), or synchrotron (EXAFS or STXM-XANES, see for phyllosilicates, Bourdelle et al., 2013b; de Andrade et al., 2014). Recent thermometer formulations coupled with these nanometric-scale analytical techniques (Bourdelle et al., 2013c) allow one to obtain accurate temperature estimations, and open new prospects for the study of low-grade rocks (Vidal et al., 2016).

In this study, we use recent analytical developments coupling FIB and TEM-EDX to characterize the chemistry of chlorite down to the nanoscale. We have targeted the Glarus Alps (Switzerland) which are one of the reference zones for low-grade metamorphism and where chlorite occurs all along the metamorphic profile. Eighteen FIB foils (9 samples, 2 FIB foils per sample) were cut in chlorite-illite assemblages to preserve the textural relationships and were analysed with a calibrated TEM-EDX. On this analytical basis, we apply recent chlorite thermometry (Bourdelle et al., 2013a) and compare our results with previous chlorite 
thermometric studies. We then discuss the results in terms of methodology for the assessment

110 of thermal history in low-grade metamorphism and we highlight some implications for the

111 exhumation history of the Glarus Alps.

112

\section{Materials and methods}

2.1. Geological setting and sampling

\subsubsection{Geological setting}

The mountainous region of Glarus is located in the Central Alps south of the Walensee

lake (eastern Switzerland) and is cut by two main valleys along the Linth (west) and Sernft

rivers (east). This part of the Central Alps exhibits a remarkable yet rather complex geological

structure resulting from at least two orogenic cycles (Hercynian and Alpine) (e.g. Pfiffner,

1993; Schmid et al., 1996). During the Alpine phase, the whole region has been deformed and

structured resulting in a spectacular thrust (Glarus thrust) separating the Helvetic nappes in

122 the hanging wall from the Infrahelvetic complex in the footwall (Fig. 1). The Helvetic nappes are composed by Permian conglomerates (Verrucano), Jurassic and Triassic carbonates and

Tertiary flyschs (e.g. Rahn et al., 1995; Merriman and Frey, 1999), while the Infrahelvetic

complex is made by the crystalline basement of the Aar massif and its parautochthonous

cover including Cretaceous and Cenozoic sediments (flyschs). The activity of the Glarus

thrust from Eocene to mid-Miocene resulted in burial of the Infrahelvetic units and

131 Further details on the local geology are given by Milnes and Pfiffner (1977), Pfiffner (1986),

132 and Pfiffner et al. (1990). 

study of the Glarus area and observed the following southward succession of index minerals: kaolinite close to Glarus, pyrophyllite and glauconite in the surroundings of Schwanden, stilpnomelane and pumpellyite between Linthal and Panix Pass, biotite and chloritoid to the south (Panix Pass). These authors also documented a transition from illite to muscovite using

140 chemical and structural analyses, and an illite crystallinity index (IC) decreasing from the 141 north (IC $>0.42^{\circ} 2 \theta$ ) to the south (IC $<0.25^{\circ} 2 \theta$ ) of the area (see also Frey, 1988; Wang et

142 al., 1996). In addition, calcite-dolomite thermometry data (Ebert et al., 2007) combined with

143 phase-relation data show a gradient in metamorphism from NW to SE, i.e. from advanced

144 diagenesis in the surroundings of Walensee lake and Glarus up to greenschist-facies

145 conditions around Panix Pass, reflecting southward increasing thermal overprint due to

146 increasing burial. This gradient was also observed by Mullis (1979), Frey (1986) and

147 Tarantola et al. (2007) by investigating fluid inclusions. To the west of Walensee lake, a

148 hydrocarbon-rich zone was identified (HHC: higher hydrocarbons), whereas methane $\left(\mathrm{CH}_{4}\right.$

149 zone, anchizone indicator) was found by going south to Linthal (Linth valley) and Engi

150 (Sernft valley). These two locations mark the limit between the $\mathrm{CH}_{4}$ zone and a $\mathrm{H}_{2} \mathrm{O}$ zone, to 151 the south of which the fluid inclusions consist mostly of $\mathrm{H}_{2} \mathrm{O}$. Vitrinite reflectance (Rahn et 152 al., 1994, 1995; Merriman and Frey, 1999; Tarantola et al., 2007; Mullis et al., 2017) also 153 records a thermal variation from Walensee to Panix Pass. Whereas vitrinite reflectance data 154 show a very low-rank coal to the north, with $\operatorname{Rmax}=0.77 \%$ (indicator of $100-120{ }^{\circ} \mathrm{C}$ ), they 155 refer to anthracite around Panix Pass, with $\mathrm{Rmax}>8 \%$ (indicator of $T>270{ }^{\circ} \mathrm{C}$ ). This is 156 confirmed by the evolution of the Raman spectrum of carbonaceous material which is 157 characteristic of very disordered graphitic carbon, with a marked southward increase of 158 structural ordering (Lahfid et al., 2010). All these independent proxies (noted "independent 159 conventional thermometers") give information on peak metamorphism (noted "maximum 160 temperature" below); they concur to the picture of a NW-SE thermal gradient (Fig. 1) which 
can be approximated by a linear regression linking maximum temperature and structural

162 distance through the Glarus Alps (Ebert et al., 2007).

163

164

165

166

167

168

169

170

171

172

173

174

175

176

177

178

179

180

181

182

183

184

185

186

Constraints on pressure are poor, and only based on the $b_{0}$ crystallographic parameter (Sassi and Scolari, 1974) of micas in the North-Helvetic flyschs (2.0-2.5 kbar, Frey, 1988), and on fluid inclusion data around Elm (2.0-2.4 kbar; Bowers and Helgeson, 1983; Potter and Brown, 1977; Tarantola et al., 2007; Caumon et al., 2014). By extrapolation, considering these works and the barometric gradient (lithostatic pressure assumed; Frey, 1988), we can approximately estimate pressures of 1.3-1.5 kbar close to Walensee Lake, 1.5-2.0 kbar in the surroundings of Glarus, 2.0-2.4 kbar around Elm, and 2.4-3.0 kbar at Panix Pass.

\subsubsection{Sampling}

Samples come from the Cenozoic North-Helvetic flyschs (Infrahelvetic complex;

Table 1; Fig. 1) in the footwall of the Glarus thrust, which have undergone only one metamorphic cycle, i.e. the Alpine orogeny. Eleven samples were collected along a N-S profile around Elm (along the Sernft valley, following the regional thermal gradient), and nine were selected (two samples were analysed but finally discarded because FIB foils were not correctly cut through chlorite-illite contacts, see below). As the chlorite thermometer used here is based on chlorite + quartz equilibrium (see section 2.2), all the samples were selected based on the presence of quartz (even samples with calcschist lithology; Table 1). From the data compilation of Ebert et al. (2007), a metamorphic peak temperature can be assigned by interpolation to each of our samples (Table 1), from $245^{\circ} \mathrm{C}$ north of Elm to $330{ }^{\circ} \mathrm{C}$ south of Panix pass.

2.2. Chlorite thermometers and barometer Investigating the relationship between chlorite composition and crystallization temperature in geothermal fields of Salton Sea and Los Azufres, Cathelineau (1988) showed 
that chlorite $\mathrm{Al}^{\mathrm{IV}}$ content increases with temperature, and established the following linear

188

189

190

191

192

193

194

195

196

197

198

199

200

201

202

203

204

205

209

211 where $A$ and $B$ are constants, $\Delta G_{r}^{0}$ the Gibbs free energy of reaction, and $R$ the gas constant.

212 With this approach, effects of pressure are neglected; this assumption is especially justified in regression:

$$
T^{\circ} \mathrm{C}=-61.92+321.98\left(\mathrm{Al}^{\mathrm{IV}} \mathrm{apfu}\right)
$$

where $\mathrm{Al}^{\mathrm{IV}}$ is expressed in atoms per 18 oxygen formula unit. This pioneer equation became the most used chlorite thermometer (including studies of Glarus metamorphism) and is the base of several other empirical thermometers (Kranidiotis and McLean, 1987; Cathelineau, 1988; Hillier and Velde, 1991; Jowett, 1991). However, empirical equations have shown their limits: Bourdelle and Cathelineau (2015) demonstrate that these equations are all specific cases of the $\mathrm{Si}_{-1} \square_{-1} \mathrm{R}_{2}{ }^{2+}$ exchange vector (combining Tschermak and di/trioctahedral substitutions), linked to the geological setting in which they were calibrated, and are consequently limited to restricted chlorite compositional ranges and geological contexts. It is therefore irrelevant to apply one empirical equation rather than another in a different geological setting; Eq. 1 is applied here only to test and compare empirical thermometry to literature and semi-empirical approaches.

To circumvent limitations of empirical calibrations, semi-empirical and

thermodynamic chlorite thermometers were later proposed. Semi-empirical thermometers are ideal models based on a ratio of end-member activities and directly link the temperature to a $K$ equilibrium constant (for a chlorite + quartz equilibrium, calculated from chlorite endmembers, $\mathrm{H}_{2} \mathrm{O}$ and $\mathrm{SiO}_{2}$ activities) as:

$\log K=\frac{-\Delta G_{r}^{0}}{2.303(R \cdot T)}=\frac{A}{T}+B$

\footnotetext{
low-T/low- $P$ contexts such as the Glarus Alps.
} 
calibrated for low- $P-T$ chlorites, i.e. $T<350{ }^{\circ} \mathrm{C}$ and $P<3-4 \mathrm{kbar}$, and (ii) it does not require a

216 prior quantification of the $\mathrm{Fe}^{3+}$ content, considering that all iron is divalent. The latter assumption does not compromise reliable temperature estimation, as shown by Bourdelle and Cathelineau (2015) and Chinchilla et al. (2016). The formulation of Bourdelle et al. (2013a) considers magnesian end-members and an ordered cationic site repartition model following the recommendations of Bailey (1988) and Vidal et al. (2001) for di-trioctahedral chlorites, an approach reinforced by several crystal-chemical studies (e.g. Welch et al., 1995; Inoue and Kogure, 2016). The calibrated thermometric equation is:

where $K$ is the equilibrium constant of the chlorite + quartz reaction as:

Al-free Mg-chlorite $+3 \mathrm{Mg}$-sudoite $=3 \mathrm{Mg}$-amesite +7 Quartz $+4 \mathrm{H}_{2} \mathrm{O}$

This formalism considers only the magnesian system, but that does not affect temperature estimates because the ferromagnesian substitution is not sensitive to temperature in low- $T$ contexts (for more details, see Bourdelle and Cathelineau, 2015).

Based on the same assumptions as Bourdelle et al. (2013a), but considering the pressure effect and a different set of end-members, Lanari et al. (2014) proposed a semi-empirical thermometer as:

$237 \quad T\left({ }^{\circ} \mathrm{C}\right)=\frac{203093+4996.99 P(\mathrm{kbar})}{-R \ln K+455.782}-273.15$ 
243 It is important to note that this model - as the thermodynamic model of Vidal et al. (2005,

244 2006) - excludes Si-rich chlorites ( $\mathrm{Si}>3 \mathrm{apfu}$ ); it was used here to try to estimate pressure,

245 using as input the temperature obtained with equation (3).

246 Semi-empirical thermometers were calibrated assuming $\mathrm{H}_{2} \mathrm{O}$ and $\mathrm{SiO}_{2}$ activities as

$247 a \mathrm{H}_{2} \mathrm{O}=a \mathrm{SiO}_{2}=1$. In the Glarus context, chlorites were sampled in the $\mathrm{H}_{2} \mathrm{O}$-dominated zone,

248 except for sample GL07 13 from the $\mathrm{CH}_{4}$ zone (Figure 1). Tarantola et al. (2007, 2009)

249 showed that fluid inclusions in the $\mathrm{H}_{2} \mathrm{O}$ zone along the Sernft valley are $\mathrm{CO}_{2}$-free or contain

250 less than $1 \mathrm{~mol} \%$ of $\mathrm{CO}_{2}$ and are composed by $>99$ mol\% of $\mathrm{H}_{2} \mathrm{O}$. Consequently, the $\mathrm{H}_{2} \mathrm{O}$

251 activity could be considered as close to 1 . Although it can be assumed that $\mathrm{H}_{2} \mathrm{O}$-dominated

252 fluid inclusions are formed at peak metamorphism (Tarantola et al., 2007), it is not possible to

253 determine whether the $\mathrm{H}_{2} \mathrm{O}$ activity in the system varied during exhumation. However, the

254 assumption that $a \mathrm{H}_{2} \mathrm{O}=1$ is usually reasonable under diagenetic to low-grade metamorphic

255 conditions (Inoue et al., 2009; Lanari et al., 2014). Besides, $a \mathrm{SiO}_{2}=1$ is justified in the case

256 of quartz-bearing rocks.

\subsection{Analytical techniques}

Detailed petrologic investigations of petrographic thin sections from the Glarus

samples were carried out using optical microscopy and Scanning Electron Microscopy (SEM)

to describe the texture of chlorites and precisely distinguish authigenic from detrital chlorites

262 before FIB milling. The SEM used was a Hitachi S-2500 instrument operating at $15 \mathrm{kV}$ with a $2631.5 \mathrm{nA}$ current intensity (ENS Paris).

The FIB foils were cut using the FIB 200 FEI of CP2M (University of Aix-Marseille)

with a voltage of $30 \mathrm{kV}$ and a gallium beam. The cutting intensity varied from 5000 to $50 \mathrm{pA}$, 
(2004). Eighteen FIB foils were cut from nine samples (two FIB foils by sample) across illitechlorite contacts near one end of the interface, where re-equilibration is the most likely. The thin foils were cut out with a size of approximately $15 \mu \mathrm{m}$ by $5 \mu \mathrm{m}$ and a thickness between 50 and $300 \mathrm{~nm}$. To check the preservation of the mineral crystalline structure after FIBmilling, lattice-fringe imaging was systematically carried out with the TEM.

Samples were analysed with a TEM-EDX/FIB coupled method and quantitative analyses were deduced and corrected thanks to the $t$-O-protocol (Van Cappellen and Doukhan, 1994; Bourdelle et al., 2012). The TEM-EDX used was a JEOL 2100-F at the Physics and Microanalysis Department of IFPEN Lyon-Solaize, using a 200 kV voltage, a counting time of $60 \mathrm{~s}$ and a dead time lower than $15 \%$. The current density was maintained at $1.3 \mathrm{pA} / \mathrm{cm}^{2}$. The sample tilt angle was $7^{\circ}$. In these conditions, the spot size was around $1 \mathrm{~nm}$ and defocused to $50 \mathrm{~nm}$. The TEM-EDX $K$ factors (Cliff and Lorimer, 1975) were calibrated on paragonite $(\mathrm{Na}, \mathrm{Al})$, pyrophyllite $(\mathrm{Al})$, talc $(\mathrm{Mg})$, muscovite $(\mathrm{Fe}, \mathrm{Al}, \mathrm{K})$, chlorite $(\mathrm{Fe}, \mathrm{Al})$, clintonite $(\mathrm{Mg}, \mathrm{Ca}, \mathrm{Al})$ and phengite $(\mathrm{Mg}, \mathrm{Fe}, \mathrm{K}, \mathrm{Al})$ and the standardizations were checked against electron microprobe analysis of reference clays (SMB-18; Kohler et al., 2009).

Given the high spatial resolution, the analysis points on FIB foils were targeted to reveal within-grain compositional variations. The structural formulae of chlorite were calculated on the anhydrous basis of 14 oxygens. Analyses containing $\mathrm{K}_{2} \mathrm{O}+\mathrm{Na}_{2} \mathrm{O}+\mathrm{CaO}>1$ $\mathrm{wt} \%$ (of the $100 \mathrm{wt} \%$ total of TEM-EDX analyses) were discarded.

\section{Results}

3.1. Petrology of Infrahelvetic nappe samples

The selected samples are schists ranging from calcschists to quartz-schists. SEM and optical microscopy observations reveal that the main minerals are quartz, carbonates, phyllosilicates and feldspars (albite and K-feldspars). Quartz grains are commonly angular, associated with prismatic altered feldspars. Phyllosilicates refer to micas (commonly muscovite/illite, occasionally detrital biotite in the $\mathrm{CH}_{4}$ zone) and chlorite, either detrital or 
authigenic. Several clusters of pyrite can be identified, with a framboidal or cubic habit. Generally, a calcareous matrix surrounds other minerals.

Detrital micas and chlorites are mainly observed in GL07 13 sample, i.e. in the $\mathrm{CH}_{4}$ zone (Table 1; Fig. 1), while phyllosilicates are mostly neo-formed in other samples - in the $\mathrm{H}_{2} \mathrm{O}$ zone. Under the polarizing microscope, detrital chlorites have a dark green colour with a strong pleochroism. These chlorites are well-preserved and oriented sub-parallel to the nascent schistosity of the rock. Authigenic chlorites are light green and form intergrowths with authigenic muscovite/illite sheets, along the entire profile (Fig. 2). These chlorites generally show slight deformation features. According to these microtextural observations, the intergrowths of muscovite/illite and chlorite are quite similar to those observed and considered as authigenic by Tarantola et al. (2009). The FIB foils were cut across authigenic illite-chlorite intergrowths; detrital chlorites were discarded on the basis of the microtextural criteria described above.

\subsection{Nanoscale chemical zoning in chlorites}

All analyses considered, the targeted Glarus chlorites display a Si content between 2.65 and 3.08 apfu and $\mathrm{R}^{2+}$ content (i.e. $\mathrm{Fe}^{2+}+\mathrm{Mg}^{2+}$ ) between 4.46 and 3.71 apfu, referring to di-tri-octahedral compositions with $\square<0.4$ apfu.

However, given the high spatial resolution of TEM-EDX and considering that FIB milling allows to preserve the crystal integrity, we can separate analyses into two categories: (i) crystal rim analyses, performed $\sim 50 \mathrm{~nm}$ away from illite-chlorite contacts (this distance allows one to avoid contamination through the FIB foil thickness due to adjacent minerals, see Bourdelle et al., 2012), and (ii) crystal core analyses (see Bourdelle et al., 2013c). The comparison of core and rim analyses reveals a systematic trend: for each sample, crystal rims are enriched in Si and depleted in divalent cations compared to crystal cores (Table 2). As an example, compositional data obtained on one of GL07-19 FIB foils reveal a chemical variation of chlorite over a few tens of nanometers, with divalent cation content lower than 
4.0 apfu in the crystal rim, but always higher than 4.1 apfu in the crystal core (Fig. 3). All the

322

323

324

325

326

327

analysed grains show such a compositional variation and, for any given sample, the two analysed grains show the same trend (see section 4.2). This systematic difference between crystal core and rim compositions clearly suggests a chemical zoning at the nanoscale (Bourdelle et al., 2008).

\subsection{Selection of chlorite analyses and chlorite thermometry}

As a reference and like most previous studies, we applied the empirical thermometer of Cathelineau (1988) to all chlorite analyses. To simulate EMP data, crystal rim and core analyses were interpreted together. The obtained temperatures vary between 255 and $365^{\circ} \mathrm{C}$

(Table 2) for all the samples (from north to south), in fair agreement with Rahn et al. (1995) and Ebert et al. (2007) from independent thermometers.

However, owing to the spatially resolved techniques employed here, which revealed the chemical zoning of Glarus chlorites, one is now able to consider separately crystal rim and core analyses. In addition, to clearly identify the re-equilibration or growth steps, only the "extreme" compositions should be considered (see Bourdelle et al., 2013c). Indeed, because of the difficulty to locate precisely the rim areas that recorded the last re-equilibration or the core areas that recorded the earliest re-equilibration or growth, we have considered only the three or four rim analyses and the three or four core analyses (noted "extreme" rim and "extreme" core compositions respectively) per sample (i.e. combining the two FIB foils of each sample) that represent the compositions closest to equilibrium. Equilibrium is here assessed by the extremum $\log K$ (Eq. 3), calculated from the analyses and considering the direction of the relevant reaction. The retained "extreme" rim compositions actually ignore some analyses having $\mathrm{Si}>3$ apfu (because they cannot be used further for pressure evaluation with Lanari et al. (2014) model). Therefore, the "extreme" rim results will represent a conservative estimate of (i.e. an upper bound to) the lowest (re)equilibration/growth temperatures. 
The chlorite thermometer of Bourdelle et al. (2013a) applied on the "extreme" crystal rim and core compositions yields the following results (Table 2, Fig. 4):

(1) Temperatures (from rim and core analyses) are systematically lower than maximum temperatures obtained with other independent thermometers along the sampling profile (difference in the range of ca. $50-100{ }^{\circ} \mathrm{C}$, depending on rim and core analyses).

(2) Temperatures from rim compositions are always lower than temperatures from core compositions, for any given sample. The difference ranges from 10 to $60{ }^{\circ} \mathrm{C}$.

(3) Temperatures from rim compositions are constant along the N-S profile (always around $190 \pm 20^{\circ} \mathrm{C}$, except GL07 13 sample) whereas the maximum temperatures from other

\subsection{Tentative reconstruction of the exhumation $P-T$ path}

To estimate the formation pressure from chlorite core and rim compositions, we used the thermobarometer of Lanari et al. (2014), i.e. the semi-empirical equation (5) linking $T, P$ and $\log K$ of the chlorite + quartz equilibrium, in which the $T$ estimates obtained with the Bourdelle et al. (2013a) model are used as input data (along with relevant $K$ values). Figure 5 presents the results of $P$ calculation, linking for each sample maximum $P$ - $T$ (estimated from literature, see section 2.1.2), chlorite-core and chlorite-rim thermobarometry. All chlorite core analyses give a pressure around $0.8 \mathrm{kbar}$ ( $\pm 0.2 \mathrm{kbar}$, except for GL07 21), while pressures estimated from chlorite rim analyses are around $0.3 \mathrm{kbar}( \pm 0.2 \mathrm{kbar})$ for samples from the south of the Glarus area (from GL07 19 sample to Elm) and around $1.3 \mathrm{kbar}$ ( $\pm 0.3 \mathrm{kbar})$ for samples from the north (from Elm to GL01 13 sample). Therefore, the south of the area 370 displays a regular P-T exhumation path (except GL07 20 sample), from $3.0 \pm 0.2 \mathrm{kbar}$ and $371310 \pm 20{ }^{\circ} \mathrm{C}$ for maximum $P-T$, to $\sim 0.8 \mathrm{kbar}$ and $\sim 220{ }^{\circ} \mathrm{C}$ for chlorite cores, and to $\sim 0.3 \mathrm{kbar}$ and $190{ }^{\circ} \mathrm{C}$ for chlorite rims. On the contrary, the north of the area shows an apparent break in 373 the exhumation, with $P$ estimates higher for chlorite rims $(\sim 1.3 \mathrm{kbar})$ than chlorite cores $(\sim 0.8$ 374 kbar). All these pressure data may be too low, if one considers the geothermal gradients 
implied; they should indeed not be taken at face value, considering that the reported

376

377

378

379

380

381

382

383

384

385

386

uncertainties are just the standard deviation; they do not include propagation of analytical error nor the unknown but likely poor accuracy of the barometer (due to the low pressure dependence of chlorite composition in low-P-T contexts, Bourdelle et al., 2013a). However, regardless of absolute values, the differential of core and rim data and its regional pattern are solid, model-independent results. As will be shown below, the consistency of the results, both in rim/core temperature evolutions and in the areal distribution of the rim/core pressure difference, supports the equilibrium-thermodynamics approach and suggests two different exhumation histories for the northern and the southern part of the Glarus Alps.

\section{Discussion}

4.1. Micro- vs. nano-scale analysis

Our results show the necessity of using high-resolution spatially resolved techniques to analyse properly chlorites (as well as micas) in a low-grade metamorphic setting like the Glarus Alps. Indeed, the results using a recent chlorite thermometer and considering the nanoscale chlorite zoning are significantly different from those obtained on the same chlorite via conventional thermometers and empirical chlorite thermometers coupled with microscale analysis like EMPA.

Previous studies on Glarus chlorites used EMPA, which has a sampling volume of several $\mu \mathrm{m}^{3}$ that does not allow identifying any compositional variation in submicrometric crystals. Glarus chlorites were therefore considered to have a homogeneous composition (Rahn et al., 1994). However, several chlorite compositions may coexist in the same rock sample or even in the same crystal, such as detrital, authigenic and/or metamorphic compositions (e.g. Bourdelle et al., 2013c). Only specific low- $T$ cases, such as homogeneous chlorites directly precipitated from fluids make it possible to avoid a nanometric analytical protocol and yet to obtain compositions suitable for thermometry (Mamane Mamadou et al., 2016). Moreover, contaminations of chlorite analyses by quartz - which can strongly impact 
402

403

404

405

406

407

408

409

410

thermometric calculation, especially with empirical thermometers - are undetectable in EMPA (see Schmidt et al., 1999 on chlorites from Taveyanne greywacke, Switzerland). Thanks to the excellent microtextural control offered by imaging modes down to the nanoscale, such contaminations are avoidable using TEM; contamination of chlorite analysis by a few smectite or illite layers is still possible, but (i) is limited by exclusion of analyses containing $\mathrm{K}_{2} \mathrm{O}+\mathrm{Na}_{2} \mathrm{O}+\mathrm{CaO}>1 \mathrm{wt} \%$ and (ii) does not influence thermometric calculation (Bourdelle et al., 2015).

4.2. Significance of chlorite compositional variations, local equilibrium vs. kinetics The EMP analyses of detrital chlorites (not presented here) show Si contents significantly lower $(<2.6 \mathrm{apfu})$ than the crystal-core analyses obtained by TEM on authigenic chlorites. As a consequence, crystal core compositions must be considered as the result of growth or re-equilibration of (prograde?) authigenic chlorite and not as a detrital relic.

A key issue is then the significance of compositional variations revealed by this study. The formation of chlorite takes place during metamorphic reactions which are transient disequilibrium states governed by local chemical potential gradients and kinetic processes. Its re-equilibration may proceed through diffusion or, more likely, dissolution-reprecipitation $(c f$. Putnis and Putnis, 2007; Putnis, 2009). Is then the observed compositional variability of chlorite the compositional record of reaction kinetics, or the record that local, grain-boundary equilibrium was achieved and maintained during growth or re-equilibration of a given metamorphic stage? Only in the latter case can the equilibrium-thermodynamic approach inherent to the applied thermometers be justified. The question must be addressed before any thermobarometric or geological consequence can be envisaged.

One way to address the equilibrium issue is through the consistency or heterogeneity of the compositional variations. In case kinetics and local-scale factors prevailed, one would expect different zoning in each grain depending on the local environment. If grain-boundary equilibrium prevailed, a local and larger-scale consistency is to be expected in the zoning 
patterns. In other words, can the assumption of local equilibrium, which has been shown to

offer a valid conceptual framework at the micro- to millimetre scale in higher-grade metamorphic terranes, also be valid in low-grade environments, then of course at nanoscale?

432 This issue, which is of general bearing, is tested below on the basis of two case studies for 433 which nanoscale data are available, the Glarus Alps (this study) and the advanced diagenesis of Gulf Coast sandstones, Texas (Bourdelle et al., 2013c).

The Glarus samples provide a first test of within-sample consistency. As explained in section 2.3, for each sample, compositional data were obtained from two FIB sections extracted from two different chlorite grains, and merged. They were merged, indeed, because the zoning patterns recorded were consistently the same in the two crystals of each pair of FIB foils. This is illustrated in Figure 6 for the representative sample GL07 17, about halfway in the Glarus transect. This figure depicts the $\mathrm{Si}$ and $\mathrm{R}^{2+}$ contents for rim and core of two different grains named B1 and A2. For clarity, we have considered only the four rim analyses and the four core analyses per grains (i.e. for B1 and A2) that give the extremum $\log K$ (Eq. 3; see section 3.3). It appears that crystal rims display a similar composition ( $\mathrm{Si}$ content between 2.72 and 2.83 apfu, $\mathrm{R}^{2+}$ content between 4.16 and 4.24 apfu). Likewise the crystal cores of B1 and A2 grains show a similar "extreme" composition. Furthermore, the compositional trend from core to rim is not only the same within sample, but it is consistently observed along the whole transect, in all samples, with calculated rim temperatures consistently lower than core temperatures, whatever they mean. Last, a second type of inter-sample regional-scale consistency exists, with the northern samples showing higher or marginally higher calculated rim pressures than core pressures, whatever they mean, and the southern samples showing the reverse (Fig. 5). It seems unlikely that such within-sample and regional consistencies could be achieved if kinetics and local factors were controlling chlorite composition.

A similar conclusion was reached from the study of Gulf Coast chlorites (Bourdelle et al., 2013c). In chlorites sampled at different depths and various locations of the Gulf Coast area, TEM and FIB techniques highlight consistent within-grain patterns of major-elements 
variations (see also Fig. 11 in Vidal et al. 2016). There, the zoning of chlorite at a nanoscale is

457 due to various crystallization stages during burial, with a core composition corresponding to

458 detrital chlorite and a rim composition of neo-formed chlorite. Moreover, the chlorite rim

459 compositions display a $T$ dependence with depth and location that is consistent with the

460 diagenetic history described at a regional scale (see Bourdelle et al., 2013c). This $T$

461 dependence of chlorite rim compositions, independently of chlorite core, clearly supports the

462 idea that the zoning of low-grade chlorites is not controlled by a kinetic effect but rather by

463 local equilibrium, in this case-study too. These observations lend credence to the

464 thermometric approach used here, the results of which are further discussed below.

4.3. Thermometric implications of the compositional zoning of Glarus chlorite

The identification of chemical zoning in the Glarus chlorites has major thermometric

implications. The fact that $T$ estimates from EMP analysis of Glarus chlorites using an

empirical thermometer are similar to maximum temperatures (Table 2) from other

independent thermometers is a coincidence, resulting from the use of a low-spatial-resolution

Bourdelle and Cathelineau (2015) for more explanations on the applicability of empirical

thermometers). This erroneously led earlier authors to conclude that authigenic chlorites

474 formed during the maximum burial step of the Glarus rocks and were not re-equilibrated

475 during exhumation. In fact, along the sampling profile, temperatures from independent

476 conventional thermometers are clearly higher than results of chlorite semi-empirical

477 thermometry (Bourdelle et al., 2013a) applied to crystal core and rim compositions (Table 2),

478 indicating different temperatures for different re-equilibration steps.

479 The chemical zoning identified in the Glarus chlorites is approximated through two

480 sets of compositional data (from rims and cores) generating two sets of estimated

481 temperatures, to be compared with the temperatures from independent conventional

482 thermometers (maximum $T$ ). Considering that independent thermometers give the peak 
metamorphic temperature (Ebert et al., 2007), that crystal-core compositions are not detrital, and that $T$ (core) $>T($ rim), the three arrays of $T$ estimates (in black, red and blue on Fig. 4) are assumed to correspond to two snapshots along the retrograde path recorded by chlorites. The first one is the re-equilibration of prograde chlorites that may happen due to fluid-rock interactions during the early exhumation and/or by chloritization of residual detrital biotites. The latter case may be valid when $T$ estimate from core is close to maximum $T$, considering that biotite chloritization may be assigned to peak metamorphism with a fluid-controlled mineralogical isograd (Tarantola et al., 2009). The second one is the re-equilibration of the chlorite rims during the late stages of the exhumation.

\subsection{Geological interpretations}

Compositional variations within a chlorite crystal are not easy to detect. Even using the latest developments of the TEM-EDX/FIB coupling, it is difficult to understand whether the zoning observed represents a progressive zoning from core to rim (continuous evolution from core to rim) or is due to the juxtaposition of different compositions (i.e., several juxtaposed and independent zones in a same chlorite, each with a specific composition). Therefore, we distinguish only two populations of chlorite compositions: core versus rim. Assuming that tens of analyses on two FIB foils for each of nine samples are representative (see Bourdelle et al., 2013c) and that targeted crystal rims refer to the late stages of the retrograde path, we can study the exhumation via the difference between the maximum temperature undergone by rocks (from independent conventional thermometers) and the temperature of the last recorded step of equilibration (our data retrieved from crystal rims). Figure 7 shows this difference (noted $\Delta T$ ) along the sampling profile. We observe that $\Delta T$ noticeably increases from Schwanden-Elm to Panix Pass. This evolution of $\Delta T$ would indicate a difference in exhumation rate between North and South with the southern part of the Glarus area going up faster, if we consider that rims of all chlorites of the area crystallized simultaneously. The latter hypothesis, i.e. synchronous crystallization of chlorite rims, is 
supported by the fact that (i) all chlorite rim compositions give similar temperatures $(190 \pm$ $20^{\circ} \mathrm{C}$ ) and (ii) all chlorites are affected by a similar slight deformation, implying a formation

512 preceding or contemporaneous to one or several tectonic deformations.

Rahn and Grasemann (1999), using fission-track data and numerical thermal modelling, proposed a scenario for exhumation including variations of the exhumation rate from the North to the South. The scenario starts $10 \mathrm{Ma}$ ago and takes into account (i) a rotation of the southern area during the retrograde step (with a rotation point assumed at the north of the Alpine border in the south of the Molasse basin), (ii) erosion and (iii) the present topographic relief. The variations of the exhumation rate (i.e. from North to South) proposed by the authors and those of the $\Delta T$ parameter presented here converge. Therefore, based on the temperatures estimated in the present study and the isotherms calculated by Rahn and Grasemann (1999), the chlorite rims would have crystallized around or a little more than 10 Ma ago. To reconcile the rotation scenario (between $10 \mathrm{Ma}$ and present), the maximum temperatures (which increase from North to South), and the variation of $\Delta T$, we can envisage (i) an exhumation that would have begun much earlier than in the scenario proposed by Rahn and Graseman (1999), with northern units initially less buried than the southern ones (crystallisation of chlorite cores), followed by (ii) a step at 10-12 Ma where northern and southern units are approximately at the same depth and during which the chlorite rims (re)crystallized, and finally by (iii) an exhumation to the surface, with the southern part exhumed structurally above the northern one. This scenario is summarized in Figure 8. The chemical zoning of Glarus chlorite also gives valuable pressure information. Therefore, chlorite core and chlorite rim thermobarometry allowed us to outline the $P-T$ retrograde path, and to identify a difference in exhumation history between the northern and southern parts of the studied area. These two retrograde paths could be linked to the exhumation scenario proposed above, completed by either (i) a slight compression step for the north of the area around 10-12 Ma, explaining the estimated $P$ increase, or (ii) a differential exhumation rate between the north and the south, or a combination of both scenarios. 
Scenario (i) would imply a thrust fault somewhere to accommodate the compression but there

538 is no direct trace or evidence for a blind fault within the studied unit. Scenario (ii) implies that

539 the southern rocks would be exhumed fast enough so that temperature would not reequilibrate

540 during decompression, whereas the northern rocks would be exhumed at a slower rate. This

541 latter scenario is in agreement with the discussion above and observations from Rahn and

542 Grasemann (1999), although we note that their conclusions deal with the shallowest part of

543 exhumation, as the apatite closure temperature is estimated at ca. $110-130{ }^{\circ} \mathrm{C}$.

\section{Conclusion}

Over the last years, chlorite thermometry has made important progress and, combined

with high-spatial-resolution analytical techniques, it allows one to obtain accurate temperature estimates, even in advanced diagenesis or very low-grade metamorphic contexts. Therein, selecting a thermometer should carefully consider all assumptions and the applicability field

550 for this thermometer with regard to the case study. In addition, the analytical protocol should 551 be chosen according to the targeted chlorites: EMP for homogeneous - large grain sizes 552 chlorites, TEM-EDX/FIB for heterogeneous - small grain sizes - chlorites. Studying the

553 Glarus Alps metasediments, we show that low- $T$ chlorites can record the retrograde rock 554 history, and that earlier interpretations made on the basis of chlorite empirical thermometry 555 must take this into account. In Glarus, past interpretations imply a crystallization of chlorites during the maximum burial step without re-equilibration during exhumation. These chlorites are actually heterogeneous and record a succession of re-equilibrations, giving new keys to understand the $P-T$ history of this part of the Central Alps.

\section{Acknowledgements}

We are most grateful to the materials characterization department of IFP Energies

562 Nouvelles-Lyon, in particular to F. Moreau, for technical advice. Thanks are also extended to 563 W. Saikaly, C. Dominici and M. Cabié, CP2M-Université Aix-Marseille. We are most 
grateful for the challenging reviews of A. Tarantola and an anonymous referee, and for the

565

editorial insight of M. Scambelluri, which helped us to strengthen and clarify our line of argument. This study was financially supported by IFP Energies Nouvelles, CNRS and ENS Paris. Funding by Partenariat Hubert Curien (Germaine de Stael) to OB is acknowledged.

\section{References}

Bailey, S.W., 1988. Chlorites: structures and crystal chemistry, in: Bailey SW (eds.), Hydrous Phyllosilicates (Exclusive of Micas), vol 19. Reviews in Mineralogy, Mineralogical Society of America, Washington, pp 347-403.

Bourdelle, F., Cathelineau, M., 2015. Low-temperature chlorite geothermometry: a graphical representation based on a T-R ${ }^{2+}-S i$ diagram. European Jourmal of Mineralogy 27, 617-626.

Bourdelle, F., Parra, T., Beyssac, O., El Albani, A., Kohler, E., 2008. Chemical variations of the micas and chlorites compositions along natural geothermal gradient: Example of Helvetic Alps (Glarus). Abstracts of paper of the American Chemical Society, 5-GEOC, 235, 235th American-Chemical-Society National Meeting, New Orleans, USA, April 2008.

Bourdelle, F., Parra, T., Beyssac, O., Chopin, C., Moreau, F., 2012. Ultrathin section preparation of phyllosilicates by Focused Ion Beam milling for quantitative analysis by TEM-EDX. Applied Clay Science 59-60, 121-130.

Bourdelle, F., Parra, T., Chopin, C., Beyssac, O., 2013a. A new chlorite geothermometer for diagenetic to low-grade metamorphic conditions. Contributions to Mineralogy and Petrology 165, 723-735.

Bourdelle, F., Benzerara, K., Beyssac, O., Cosmidis, J., Neuville, D.R., Brown, G.E. Jr, Paineau, E., 2013b. Quantification of the ferric/ferrous iron ratio in silicates by scanning transmission X-ray microscopy at the Fe L2,3 edges. Contributions to Mineralogy and Petrology 166, 423-434. 
Bourdelle, F., Parra, T., Beyssac, O., Chopin, C., Vidal, O., 2013c. Clay minerals as geothermometer: A comparative study based on high spatial analyses of illite and chlorite in Gulf Coast sandstones (Texas, U.S.A.). American Mineralogist 98, 914-926.

592 Bowers, T.S., Helgeson, H.C., 1983. Calculation of the thermodynamic and geochemical 593 consequences of non-ideal mixing in the system $\mathrm{H}_{2} \mathrm{O}-\mathrm{CO}_{2}-\mathrm{NaCl}$ on phase-relations in 594 geologic systems-metamorphic equilibria at high-pressures and temperatures. American $595 \quad$ Mineralogist 68, 1059-1075.

596 Cathelineau, M., 1988. Cation site occupancy in chlorites and illites as a function of 597 temperature. Clay Minerals 23, 471-485.

598 Cathelineau, M., Nieva, D., 1985. A chlorite solid solution geothermometer. The Los Azufres 599 (Mexico) geothermal system. Contributions to Mineralogy and Petrology 91, 235-244. 600 Caumon, M-C., Robert, P., Laverret, E., Tarantola, A., Randi, A., Pironon, J., Dubessy, J., 601 Girard, J-P., 2014. Determination of methane content in $\mathrm{NaCl}-\mathrm{H}_{2} \mathrm{O}$ fluid inclusions by 602 Raman spectroscopy. Calibration and application to the external part of the Central Alps 603 (Switzerland). Chemical Geology 378-379, 52-61.

604 Chinchilla, D., Arroyo, X., Merinero, R., Piña, R., Nieto, F., Ortega, L., Lunar, R., 2016. 605 Chlorite geothermometry applied to massive and oscillatory-zoned radiated Mn-rich 606 chlorites in the Patricia Zn-Pb-Ag epithermal deposit (NE, Chile). Applied Clay Science $607 \quad 134,210-220$.

608 Cliff, G., Lorimer, G.W., 1975. The quantitative analysis of thin specimens. Journal of $609 \quad$ Microscopy 103, 203-207.

610 De Andrade, V., Ganne, J., Dubacq, B., Ryan, C. G., Bourdelle, F., Plunder, A., Falkenberg, 611 G., Thieme, J., 2014. Retrieving past geodynamic events by unlocking rock archives with $612 \mu$-XRF and $\mu$-spectroscopy. In Journal of Physics: Conference Series (Vol. 499, No. 1, p. 613 012012). IOP Publishing.

614 de Caritat, P., Hutcheon, I., Walshe, J.L., 1993. Chlorite geothermometry: a review. Clays and 615 Clay Minerals 41, 219-239. 
Ebert, A., Herwegh, M., Pfiffner, A., 2007. Cooling induced strain localization in carbonate mylonites within a large-scale shear zone (Glarus thrust, Switzerland). Journal of Structural Geology 28, 1164-1184.

Frey, M., 1986. Very low-grade metamorphism of the Alps - an introduction. Schweizerische Mineralogische und Petrographische Mitteilungen 66, 13-27.

Frey, M., 1988. Discontinuous inverse metamorphic zonation, Glarus Alps, Switzerland: evidence from illite "crystallinity" data. Schweizerische Mineralogische und Petrographische Mitteilungen 68, 171-183.

Frey, M., Ferreiro Mählmann, R., 1999. Alpine metamorphism of the Central Alps. Schweizerische Mineralogische und Petrographische Mitteilungen 76, 159-164.

Ganne, J., De Andrade, V., Weinberg, R.F., Vidal, O., Dubacq, B., Kagambega, N., Naba, S., Baratoux, L., Jessell, M., Allibon, J., 2012. Modern-style plate subduction preserved in the Palaeoproterozoic West African craton. Nature Geoscience 5, 60-65.

Heaney, P.J., Vicenzi, E.P., Giannuzzi, L.A., Livi, K.J.T., 2001. Focused ion beam milling: a method of site-specific sample extraction for microanalysis of Earth and planetary materials. American Mineralogist 86, 1094-1099.

Hillier, S., Velde, B., 1991. Octahedral occupancy and the chemical-composition of diagenetic (low-temperature) chlorites. Clay Minerals 26, 149-168.

Hunziker, J.C., Frey, M., Clauer, N., Dallmeyer, R.D., Friedrichsen, H., Flehmig, W., 635 Hochstrasser, K., Roggwiler, P., Schwander, H., 1986. The evolution of illite to muscovite: 6 mineralogical and isotopic data from the Glarus Alps, Switzerland. Contributions to Mineralogy and Petrology 92(2), 157-180.

638 Inoue, S., Kogure, T., 2016. High-angle annular dark field scanning transmission electron 39 microscopic (HAADFSTEM) study of Fe-rich $7 \AA$ A $-14 \AA$ interstratified minerals from a hydrothermal deposit. Clay Minerals 51, 603-613. 
641

642

643

644

Inoue, A., Meunier, A., Patrier-Mas, P., Rigault, C., Beaufort, D., Vieillard, P., 2009. Application of chemical geothermometry to low-temperature trioctahedral chlorites. Clays and Clay Minerals 57, 371-382.

Inoue, A., Kurokawa, K., Hatta, T., 2010. Application of chlorite geothermometry to hydrothermal alteration in Toyoha geothermal system, Southwestern Hokkaido, Japan.

$$
\text { Resource Geology 60, 52-70. }
$$

Jowett, E.C., 1991. Fitting iron and magnesium into the hydrothermal chlorite geothermometer. GAC/MAC/SEG Joint annual meeting, 16, Toronto, Canada,

\section{GAC/MAC/SEG.}

Kameda, J., Ujiie, K., Yamaguchi, A., Kimura, G., 2011. Smectite to chlorite conversion by frictional heating along a subduction thrust. Earth and Planetary Science Letters 305, 161170.

Kameda, J., Hina, S., Kobayashi, K., Yamaguchi, A., Hamada, Y., Yamamoto, Y., Hamahashi, M., Kimura, G., 2012. Silica diagenesis and its effect on interplate seismicity in cold subduction zones. Earth and Planetary Science Letters 317, 136-144.

Kohler, E., Parra, T., Vidal, O., 2009. Clayey Cap-Rock behavior in $\mathrm{H}_{2} \mathrm{O}-\mathrm{CO}_{2}$ media at low pressure and temperature conditions: an experimental approach. Clays and Clay Minerals $57,616-637$.

Kranidiotis, P., McLean, W.H., 1987. Systematics of chlorite alternation at the Phelps Dodge massive sulfide deposit, Matagami, Quebec. Economic Geology 82, 1898-1911.

Lahfid, A., Beyssac, O., Deville, E., Negro, F., Chopin, C., Goffé, B., 2010. Evolution of the Raman spectrum of carbonaceous material in low-grade metasediments of the Glarus Alps (Switzerland). Terra Nova 22, 354-360.

Lanari, P., Wagner, T., Vidal, O., 2014. A thermodynamic model for di-trioctahedral chlorite from experimental and natural data in the system $\mathrm{MgO}-\mathrm{FeO}-\mathrm{Al}_{2} \mathrm{O}_{3}-\mathrm{SiO}_{2}-\mathrm{H}_{2} \mathrm{O}$ : applications to P-T sections and geothermometry. Contributions to Mineralogy and Petrology 167, 968. 
668

669

670

671

672

673

674

675

676

677

678

679

680

681

682

683

684

685

686

687

688

689

690

691

692 693 solutions from $0{ }^{\circ}$ to $500{ }^{\circ} \mathrm{C}$ and pressures up to 2000 bars based on a regression of 694 available data in the literature. Economic Geology 73, 284-285.

Mamane Mamadou, M., Cathelineau, M., Bourdelle, F., Boiron, M-C., Elmaleh, A., Brouand, M., 2016. Hot fluid flows around a major fault identified by paleothermometric studies (Tim Mersoï basin, Niger). Journal of Sedimentary Research 86, 914-928.

Merriman, R.J., Frey, M., 1999. Patterns of very low-grade metamorphism in metapelitic rocks. In: Low-grade metamorphism, Frey and Robinson (Eds.), Blackwell Science Ltd.

Milnes, A. G., Pfiffner, O. A., 1977. Structural development of the Infrahelvetic complex, eastern Switzerland. Eclogae Geologicae Helvetiae 70(1), 83-95.

Mosser-Ruck, R., Pignatelli, I., Bourdelle, F., Abdelmoula, M., Barres, O., Guillaume, D., Charpentier, D., Rousset, D., Cathelineau, M., Michau, N., 2016. Contribution of longterm hydrothermal experiments for understanding the smectite-to-chlorite conversion in geological environments. Contributions to Mineralogy and Petrology 171(11), 97.

Mullis, J., 1979. The system methane-water as a geologic thermometer and barometer from the external part of the Central Alps. Bulletin de Minéralogie 102, 526-536.

Mullis, J., Mählmann, R. F., Wolf, M., 2017. Fluid inclusion microthermometry to calibrate vitrinite reflectance (between 50 and $270{ }^{\circ} \mathrm{C}$ ), illite Kübler-Index data and the diagenesis/anchizone boundary in the external part of the Central Alps. Applied Clay Science 143, 307-319.

Pfiffner, O.A., 1986. Evolution of the North Alpine Foreland Basin in the Central Alps. Special Publications of the International Association of Sedimentologists 8, 219-228.

Pfiffner, O.A., 1993. The structure of the Helvetic nappes and its relation to the mechanical stratigraphy. Journal of Structural Geology 15(3-5), 511-521.

Pfiffner, O.A., Frei, W., Valasek, P. et al., 1990. Crustal shortening in the Alpine Orogen: results from deep seismic reflection profiling in the eastern Swiss Alps, line NFP 20-east. Tectonophysics 9, 1327-1355.

Potter, R.W., Brown, D.L., 1977. The volumetric properties of aqueous sodium chloride 
695

696

697

698

699

700

701

702

703

704

705

706

707

708

709

710

711

712

713

715

716

720 714 Journal of Geodynamics 96, 174-193. $717 \quad 1064$.

718 Schmidt, D., Livi, K. J. T., Frey, M., 1999. Reaction progress in chloritic material: an electron 719 microbeam study of the Taveyanne greywacke, Switzerland. Journal of Metamorphic

Putnis, A., 2009. Mineral replacement reactions. Reviews in Mineralogy and Geochemistry

$$
70,87-124 \text {. }
$$

Putnis, A., Putnis, C. V., 2007. The mechanism of reequilibration of solids in the presence of a fluid phase. Journal of Solid State Chemistry 180, 1783-1786.

Rahn, M.K., Grasemann, B., 1999. Fission track and numerical thermal modeling of differential exhumation of the Glarus thrust plane (Switzerland). Earth and Planetary Science Letters 169, 245-259.

Rahn, M., Mullis, J., Erdelbrock, K., Frey, M., 1994. Very low-grade metamorphism of the Taveyanne Greywacke, Glarus Alps, Switzerland. Journal of Metamorphic Geology 12, $625-641$.

Rahn, M., Mullis, J., Erdelbrock, K., Frey, M., 1995. Alpine metamorphism in the North Helvetic Flysch of the Glarus Alps, Switzerland. Eclogae Geologicae Helvetiae 88/1, 157 178.

Sassi, F.P., Scolari A., 1974. The $b_{0}$ value of the potassic white micas as a barometric indicator in low-grade metamorphism of pelitic schists. Contributions to Mineralogy and Petrology 45, 143-152.

Scheffer, C.,Vanderhaeghe, O., Lanari, P., Tarantola, A., Ponthus, L., Photiades, A., France, L., 2016. Syn- to post-orogenic exhumation of metamorphic nappes: Structure and thermobarometry of the western Attic-Cycladic metamorphic complex (Lavrion, Greece).

15 Schmid, S.M., Pfiffner, O.A., Froitzheim, N., Schönborn, G., Kissling, E., 1996. Geophysical16 geological transect and tectonic evolution of the Swiss-Italian Alps. Tectonics 15(5), 1036Geology 17, 229-241. 
Tarantola, A., Mullis, J., Vennemann, T., Dubessy, J., de Capitani, C., 2007. Oxidation of methane at the $\mathrm{CH}_{4} / \mathrm{H}_{2} \mathrm{O}-\left(\mathrm{CO}_{2}\right)$ transition zone in the external part of the Central Alps, Switzerland: evidences from stable isotope investigations. Chemical Geology 237, 329_ 357.

Tarantola, A., Mullis, J., Guillaume, D., Dubessy, J., de Capitani, C., Abdelmoula, M., 2009. Oxidation of $\mathrm{CH}_{4}$ to $\mathrm{CO}_{2}$ and $\mathrm{H}_{2} \mathrm{O}$ by chloritization of detrital biotite at $270 \pm 5^{\circ} \mathrm{C}$ in the external part of the Central Alps, Switzerland. Lithos 112, 497-510.

Trincal, V., Lanari, P., Buatier, M., Lacroix, B., Charpentier, D. Labaume, P., Munoz, M., 2015. Temperature micro-mapping in oscillatory-zoned chlorite: Application to study of a green-schist facies fault zone in the Pyrenean Axial Zone (Spain). American Mineralogist $100,11-12$

Van Cappellen, E., Doukhan, J.C., 1994. Quantitative transmission-X-ray microanalysis of ionic compounds. Ultramicroscopy 53, 343-349.

Vidal, O., Parra, T., Trotet, F., 2001. A thermodynamic model for Fe-Mg aluminous chlorite using data from phase equilibrium experiments and natural pelitic assemblages in the $100^{\circ}$ to $600{ }^{\circ} \mathrm{C}, 1$ to $25 \mathrm{~kb}$ range. American Journal of Science $301,557-592$.

Vidal, O., Parra, T., Vieillard, P., 2005. Thermodynamic properties of the Tschermak solid solution in Fe-chlorite: Application to natural examples and possible role of oxidation. American Mineralogist 90, 347-358.

Vidal, O., De Andrade, V., Lewin, E., Munoz, M., Parra, T., Pascarelli, S., 2006. P-Tdeformation- $\mathrm{Fe}^{3+} / \mathrm{Fe}^{2+}$ mapping at the thin section scale and comparison with XANES mapping: application to a garnet-bearing metapelite from the Sambagawa metamorphic belt (Japan). Journal of Metamorphic Geology 24, 669-683.

Vidal, O., Lanari, P., Munoz, M., Bourdelle, F., De Andrade, V., 2016. Deciphering temperature, pressure and oxygen-activity conditions of chlorite formation. Clay Minerals 51(4), 615-633. 
747 Walshe, J.L., 1986. A six-component chlorite solid solution model and the conditions of

748 chlorite formation in hydrothermal and geothermal systems. Economic Geology 81, 681-

$749 \quad 703$.

750 Wang, H., Frey, M., Stern, W.B., 1996. Diagenesis and metamorphism of clay minerals in the

751 Helvetic Alps of eastern Switzerland. Clays and Clay Minerals 44, 96-112.

752 Welch, M.D., Barras, J., Klinowski, J., 1995. A multi-nuclear NMR study of clinochlore.

753 American Mineralogist 80, 441-447.

754 Wirth, R., 2004. Focused Ion Beam (FIB): a novel technology for advanced application of 755 micro- and nanoanalysis in geosciences and applied mineralogy. European Journal of $756 \quad$ Mineralogy 16, 863-876.

757 Xie, X.G., Byerly, G.R., Ferrell, R.E., 1997. IIb trioctahedral chlorite from the Barberton

758 greenstone belt: Crystal structure and rock composition constraints with implications to 759 geothermometry. Contributions to Mineralogy and Petrology 126, 275-291.

760 Zang, W., Fyfe, W.S., 1995. Chloritization of the hydrothermally altered bedrock at the 761 Igarape-Bahia gold deposit, Carajas, Brazil. Mineralium Deposita 30, 30-38. 
765 Table 1: Sample description with name, geographical position (WGS 84 coordinates), area of 766 sampling, lithology and temperature of peak metamorphism estimated by Rahn et al. (1995) 767 and Ebert et al. (2007).

\begin{tabular}{lcccccc}
\hline Structural unit & Sample & Longitude E & Latitude N & Zone & Lithology & Max $T^{\circ} \mathrm{C}$ \\
\hline Infrahelvetic nappe & GL07 13 & 9.1581 & 46.9854 & East-Schwanden & Calc-schist & 245 \\
& GL07 15 & 9.1692 & 46.9441 & Elm & Calc-schist & 280 \\
& GL07 16 & 9.1689 & 46.9319 & Elm & Quartz-schist & 285 \\
& GL07 17 & 9.1793 & 46.9214 & Elm & Schist & 295 \\
& GL07 19 & 9.1039 & 46.8514 & Panix Pass & Schist & 330 \\
& GL07 20 & 9.1108 & 46.8572 & Panix Pass & Quartz-schist & 325 \\
& GL07 21 & 9.1208 & 46.8736 & Panix Pass & Quartz-schist & 320 \\
& GL07 23 & 9.1297 & 46.8797 & Panix Pass & Schist & 310 \\
& GL07 24 & 9.1272 & 46.8872 & Panix Pass & Schist & 310 \\
\hline
\end{tabular}

Table 2: Selection of TEM-EDX analyses of Glarus chlorite. For each sample, a crystal core and crystal rim analysis are given. Max $T^{\circ} \mathrm{C}$ refers to maximum temperature (peak

780 metamorphism) obtained from independent conventional thermometers (Ebert et al., 2007).

781 Cathelineau $T^{\circ} \mathrm{C}$ : temperatures estimated with the Cathelineau (1988) thermometer (Eq. 1).

782 Bourdelle $T^{\circ} \mathrm{C}$ : temperatures estimated with the Bourdelle et al. (2013a) thermometer (Eq. 3). 


\begin{tabular}{|c|c|c|c|c|c|c|c|c|c|c|c|c|c|c|c|c|}
\hline \multirow{4}{*}{$\begin{array}{l}\text { Sampling profile } \\
\text { Sample } \\
\text { rim/core analysis } \\
\text { analysis code }\end{array}$} & \multicolumn{6}{|l|}{$\mathrm{N}$} & \multicolumn{6}{|c|}{ ELM } & \multicolumn{4}{|r|}{$\mathrm{S}$} \\
\hline & \multicolumn{2}{|c|}{ GL07 13} & \multicolumn{2}{|c|}{ GL07 15} & \multicolumn{2}{|c|}{ GL07 16} & \multicolumn{2}{|c|}{ GL07 17} & \multicolumn{2}{|c|}{ GL07 23/24 } & \multicolumn{2}{|c|}{ GL07 21} & \multicolumn{2}{|c|}{ GL07 20} & \multicolumn{2}{|c|}{ GL07 19} \\
\hline & $\operatorname{rim}$ & core & $\operatorname{Rim}$ & core & rim & core & rim & core & $\operatorname{rim}$ & core & Rim & core & rim & core & rim & core \\
\hline & A2chl1 & A1chl8 & B3chl4 & B2 chl7 & A $5 \operatorname{chl} 30$ & A5chl8 & B1chl21 & B1chl18 & C3chl1 & B2chl21 & B1chl2 & B1chl6 & A 2 chl10 & $\mathrm{A} 4 \mathrm{chl} 8$ & A2chl7 & A $3 \operatorname{chl} 20$ \\
\hline \multicolumn{17}{|c|}{ TEM-EDX analyses } \\
\hline $\mathrm{SiO}_{2}$ & 33.57 & 30.15 & 31.72 & 29.21 & 31.88 & 31.52 & 31.27 & 30.19 & 30.10 & 30.15 & 30.28 & 29.28 & 31.38 & 30.44 & 29.94 & 28.96 \\
\hline $\mathrm{TiO}_{2}$ & 0.06 & 0.00 & 0.00 & 0.08 & 0.13 & 0.00 & 0.00 & 0.00 & 0.00 & 0.00 & 0.05 & 0.08 & 0.09 & 0.01 & 0.01 & 0.00 \\
\hline $\mathrm{Al}_{2} \mathrm{O}_{3}$ & 26.38 & 27.50 & 26.40 & 29.02 & 26.71 & 24.69 & 26.63 & 27.57 & 27.55 & 26.42 & 28.45 & 27.98 & 25.02 & 25.61 & 26.32 & 26.17 \\
\hline $\mathrm{FeO}$ & 26.52 & 29.54 & 23.70 & 28.34 & 22.70 & 26.68 & 24.85 & 25.51 & 29.53 & 28.84 & 28.68 & 30.46 & 29.80 & 26.36 & 30.47 & 31.31 \\
\hline $\mathrm{MnO}$ & 0.00 & 0.00 & 0.00 & 0.00 & 0.00 & 0.00 & 0.00 & 0.00 & 0.00 & 0.00 & 0.00 & 0.00 & 0.00 & 0.00 & 0.00 & 0.00 \\
\hline $\mathrm{MgO}$ & 13.27 & 12.63 & 18.07 & 12.57 & 17.98 & 16.19 & 16.77 & 16.70 & 12.64 & 14.56 & 12.54 & 12.20 & 13.26 & 17.42 & 13.04 & 13.51 \\
\hline $\mathrm{CaO}$ & 0.11 & 0.16 & 0.00 & 0.26 & 0.55 & 0.67 & 0.03 & 0.02 & 0.03 & 0.00 & 0.00 & 0.00 & 0.00 & 0.05 & 0.00 & 0.06 \\
\hline $\mathrm{Na}_{2} \mathrm{O}$ & 0.00 & 0.00 & 0.00 & 0.20 & 0.00 & 0.25 & 0.08 & 0.00 & 0.03 & 0.00 & 0.00 & 0.00 & 0.04 & 0.00 & 0.00 & 0.00 \\
\hline $\mathrm{K}_{2} \mathrm{O}$ & 0.10 & 0.02 & 0.10 & 0.33 & 0.04 & 0.00 & 0.36 & 0.00 & 0.06 & 0.04 & 0.00 & 0.00 & 0.40 & 0.11 & 0.22 & 0.00 \\
\hline \multicolumn{17}{|l|}{ Struct. form. (apfu) } \\
\hline $\mathrm{Si}$ & 3.01 & 2.77 & 2.83 & 2.67 & 2.83 & 2.86 & 2.81 & 2.72 & 2.76 & 2.76 & 2.76 & 2.70 & 2.89 & 2.76 & 2.77 & 2.69 \\
\hline $\mathrm{Ti}$ & 0.00 & 0.00 & 0.00 & 0.01 & 0.01 & 0.00 & 0.00 & 0.00 & 0.00 & 0.00 & 0.00 & 0.01 & 0.01 & 0.00 & 0.00 & 0.00 \\
\hline $\mathrm{Al}(\mathrm{IV})$ & 0.99 & 1.23 & 1.17 & 1.33 & 1.17 & 1.14 & 1.19 & 1.28 & 1.24 & 1.24 & 1.24 & 1.30 & 1.11 & 1.24 & 1.23 & 1.31 \\
\hline $\mathrm{Al}(\mathrm{VI})$ & 1.80 & 1.74 & 1.61 & 1.80 & 1.63 & 1.51 & 1.63 & 1.65 & 1.74 & 1.61 & 1.82 & 1.74 & 1.60 & 1.50 & 1.63 & 1.56 \\
\hline $\mathrm{Fe}^{2+}$ & 1.99 & 2.27 & 1.77 & 2.17 & 1.69 & 2.03 & 1.87 & 1.92 & 2.27 & 2.21 & 2.19 & 2.35 & 2.29 & 2.00 & 2.35 & 2.43 \\
\hline $\mathrm{Mn}$ & 0.00 & 0.00 & 0.00 & 0.00 & 0.00 & 0.00 & 0.00 & 0.00 & 0.00 & 0.00 & 0.00 & 0.00 & 0.00 & 0.00 & 0.00 & 0.00 \\
\hline $\mathrm{Mg}$ & 1.78 & 1.73 & 2.40 & 1.72 & 2.38 & 2.19 & 2.25 & 2.24 & 1.73 & 1.99 & 1.70 & 1.68 & 1.82 & 2.36 & 1.80 & 1.87 \\
\hline $\mathrm{Ca}$ & 0.01 & 0.02 & 0.00 & 0.03 & 0.05 & 0.07 & 0.00 & 0.00 & 0.00 & 0.00 & 0.00 & 0.00 & 0.00 & 0.00 & 0.00 & 0.01 \\
\hline $\mathrm{Na}$ & 0.00 & 0.00 & 0.00 & 0.03 & 0.00 & 0.04 & 0.01 & 0.00 & 0.00 & 0.00 & 0.00 & 0.00 & 0.01 & 0.00 & 0.00 & 0.00 \\
\hline K & 0.01 & 0.00 & 0.01 & 0.04 & 0.00 & 0.00 & 0.04 & 0.00 & 0.01 & 0.00 & 0.00 & 0.00 & 0.05 & 0.01 & 0.03 & 0.00 \\
\hline \multicolumn{17}{|l|}{$T^{\circ} \mathrm{C}$ estimates } \\
\hline $\max T^{\circ} \mathrm{C}$ & 245 & 245 & 280 & 280 & 285 & 285 & 295 & 295 & 310 & 310 & 320 & 320 & 325 & 325 & 330 & 330 \\
\hline Cathelineau $T^{\circ} \mathrm{C}$ & 255 & 336 & 315 & 363 & 311 & 304 & 321 & 350 & 336 & 337 & 336 & 355 & 294 & 337 & 335 & 359 \\
\hline Bourdelle $T^{\circ} \mathrm{C}$ & 120 & 183 & 186 & 202 & 176 & 197 & 189 & 217 & 183 & 209 & 172 & 201 & 168 & 245 & 203 & 261 \\
\hline
\end{tabular}


784

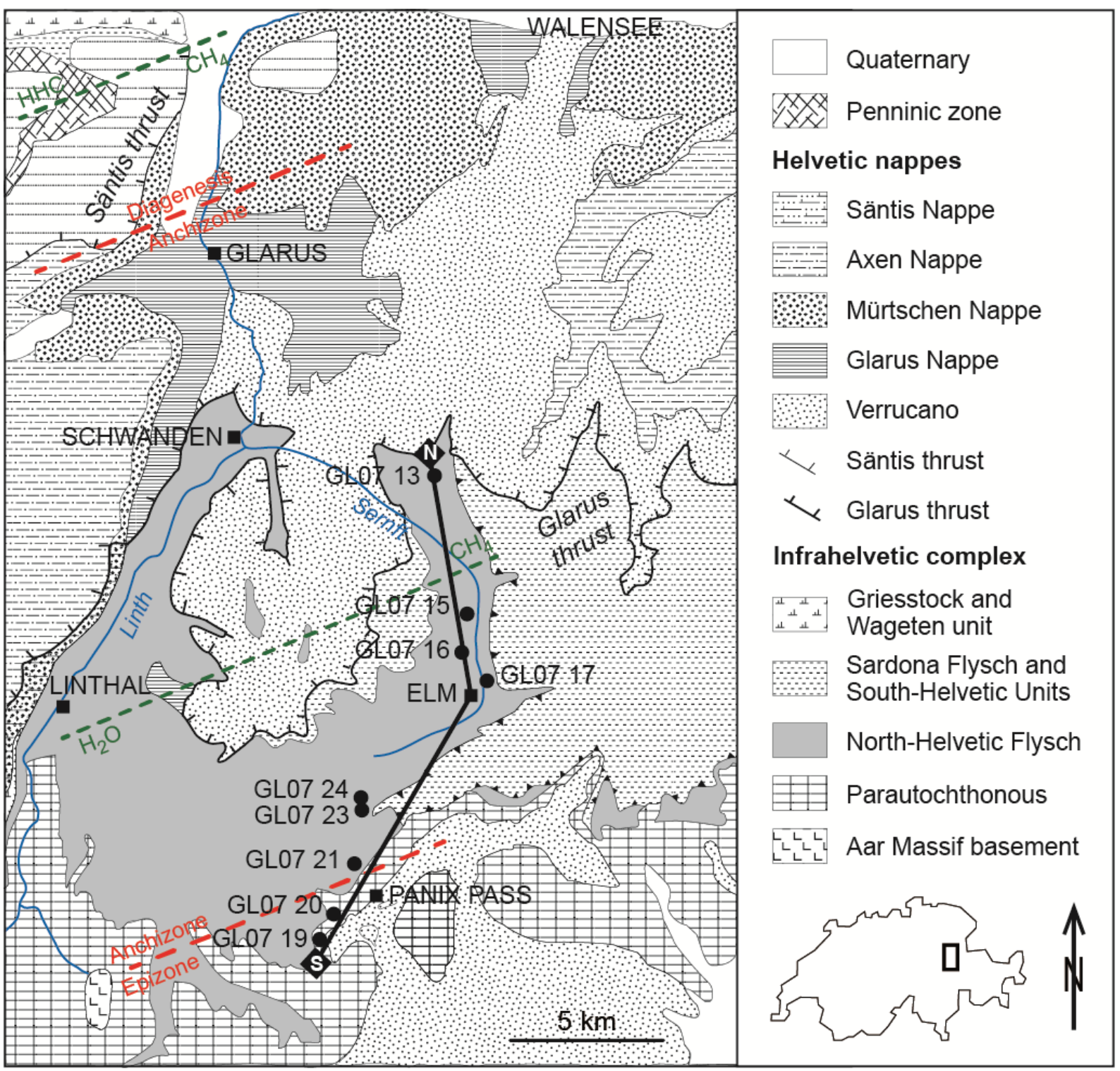

Fig. 1: Simplified geological map of the Glarus Alps (Central Switzerland). Sample location

787 and sampling N-S profile are reported. The diagenetic zone/anchizone and the

788 anchizone/epizone boundaries are depicted as red dashed lines; $\mathrm{HHC} / \mathrm{CH}_{4}$ and $\mathrm{CH}_{4} / \mathrm{H}_{2} \mathrm{O}$

789 limits based on fluid inclusion data are shown as green dashed lines (Rahn et al., 1995;

790 Merriman and Frey, 1999; Ebert et al., 2007; Tarantola et al., 2007). 

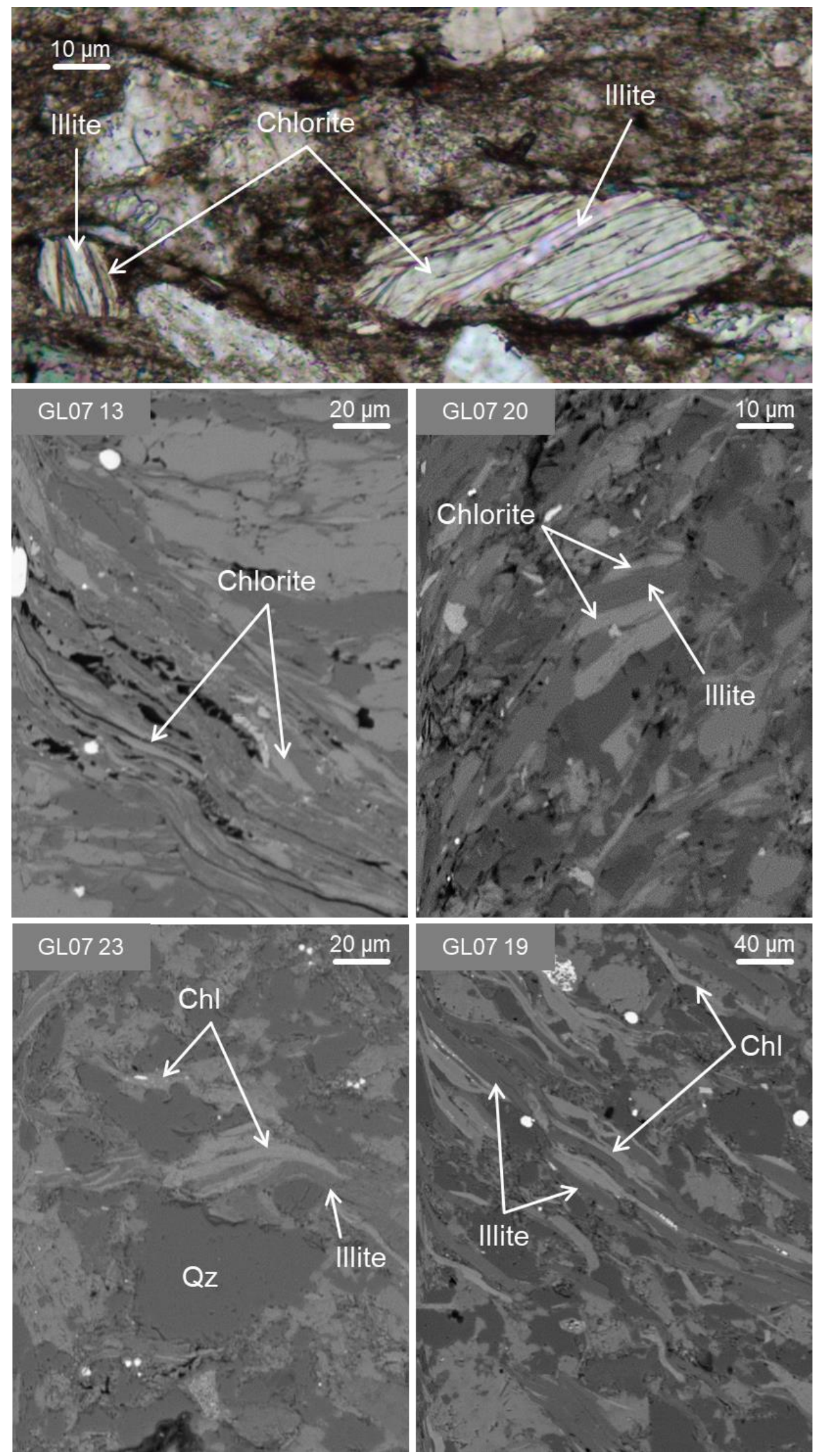

793 Fig. 2: Back-Scattered Electron SEM images of several petrographic thin sections showing

794 authigenic chlorites, and illite-chlorite intergrowth structures. On these images, chlorite

795 appears in pale grey whereas illite is in darker grey. 

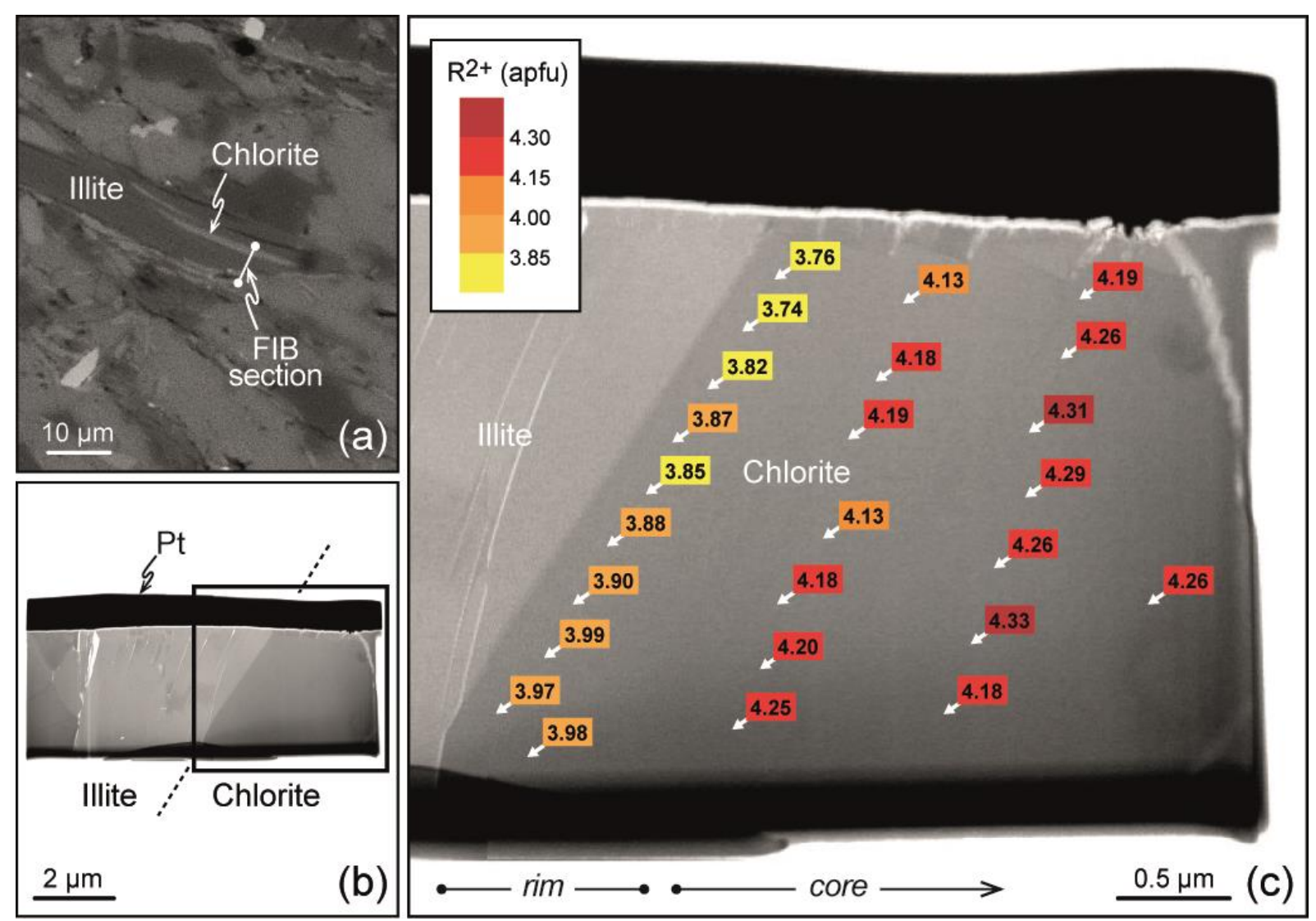

797

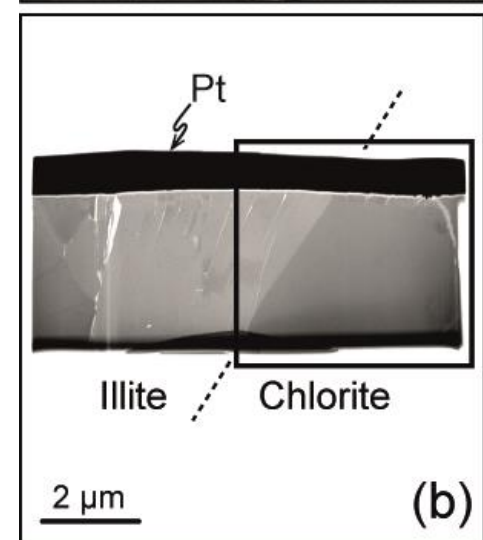

798 Fig. 3: Analysis of an illite-chlorite assemblage (GL07 19 sample). (a) SEM image of the

799 petrographic thin section showing the emplacement of the FIB foil to be cut across the illite-

800 chlorite interface. (b) Bright-field TEM image of the FIB foil extracted from the section, with

801 the platinum strap on top of it. (c) Enlargement of part b showing the $\mathrm{R}^{2+}\left(\mathrm{Fe}^{2+}+\mathrm{Mg}^{2+}\right)$

802 contents of chlorite (apfu) and their variation from crystal core to crystal rim. 


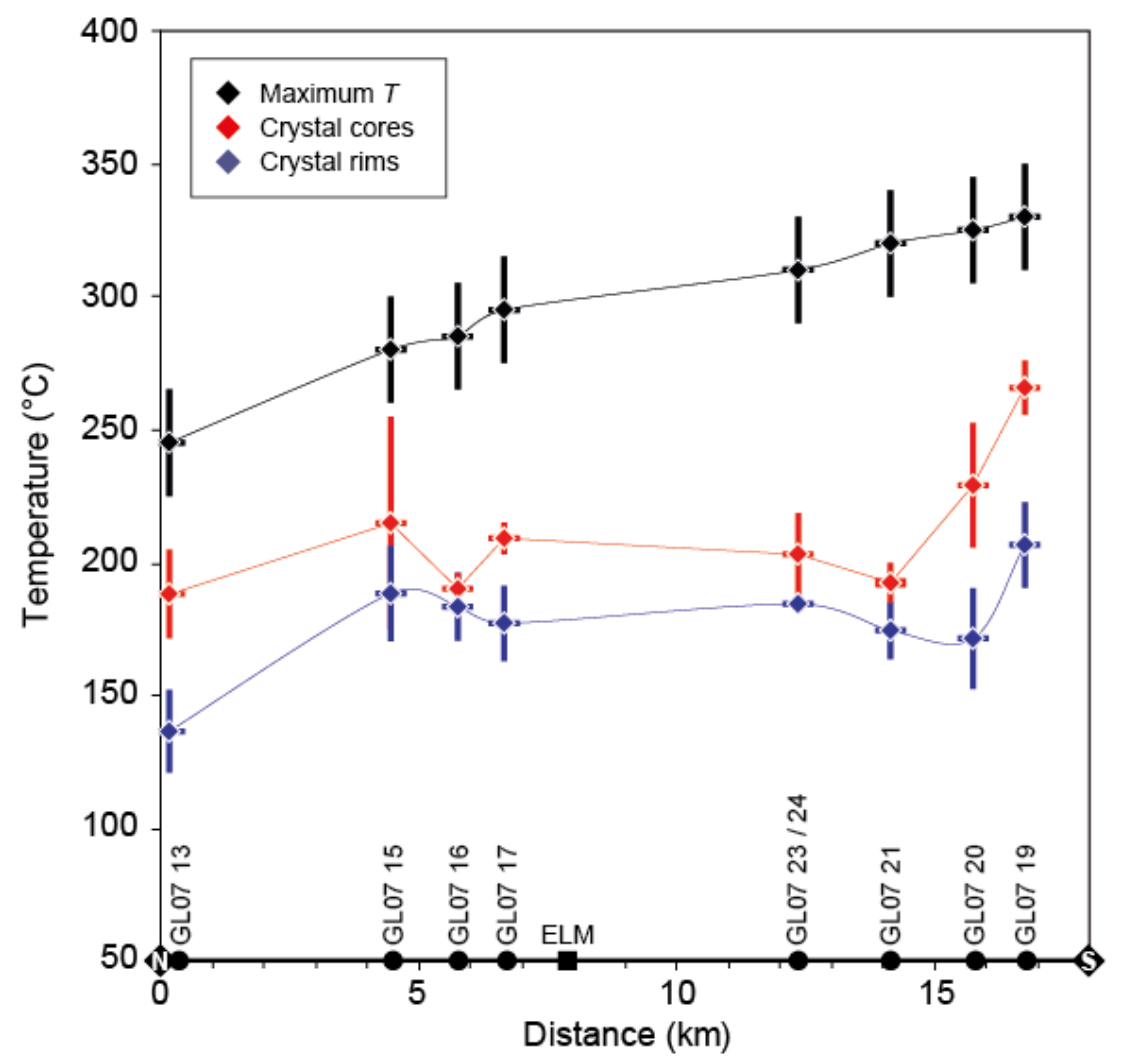

804

805 Fig. 4: Comparison of thermal profiles obtained between East-Schwanden and Panix Pass

806 from literature by a compilation of methods (in black), with Bourdelle et al. (2013a)

807 thermometer on chlorite crystal cores (in red), and with Bourdelle et al. (2013a) thermometer

808 on chlorite crystal rims (in blue). Chlorite core and rim thermometry: for each sample,

809 representation of the average of $T$ estimates from selected "extreme" chlorite compositions

810 (analysis of two FIB foils for each sample; for more details, see text). Error bars refer to

811 uncertainty given by Ebert et al. (2007) (black points) and to standard deviation (red and blue 812 points). 


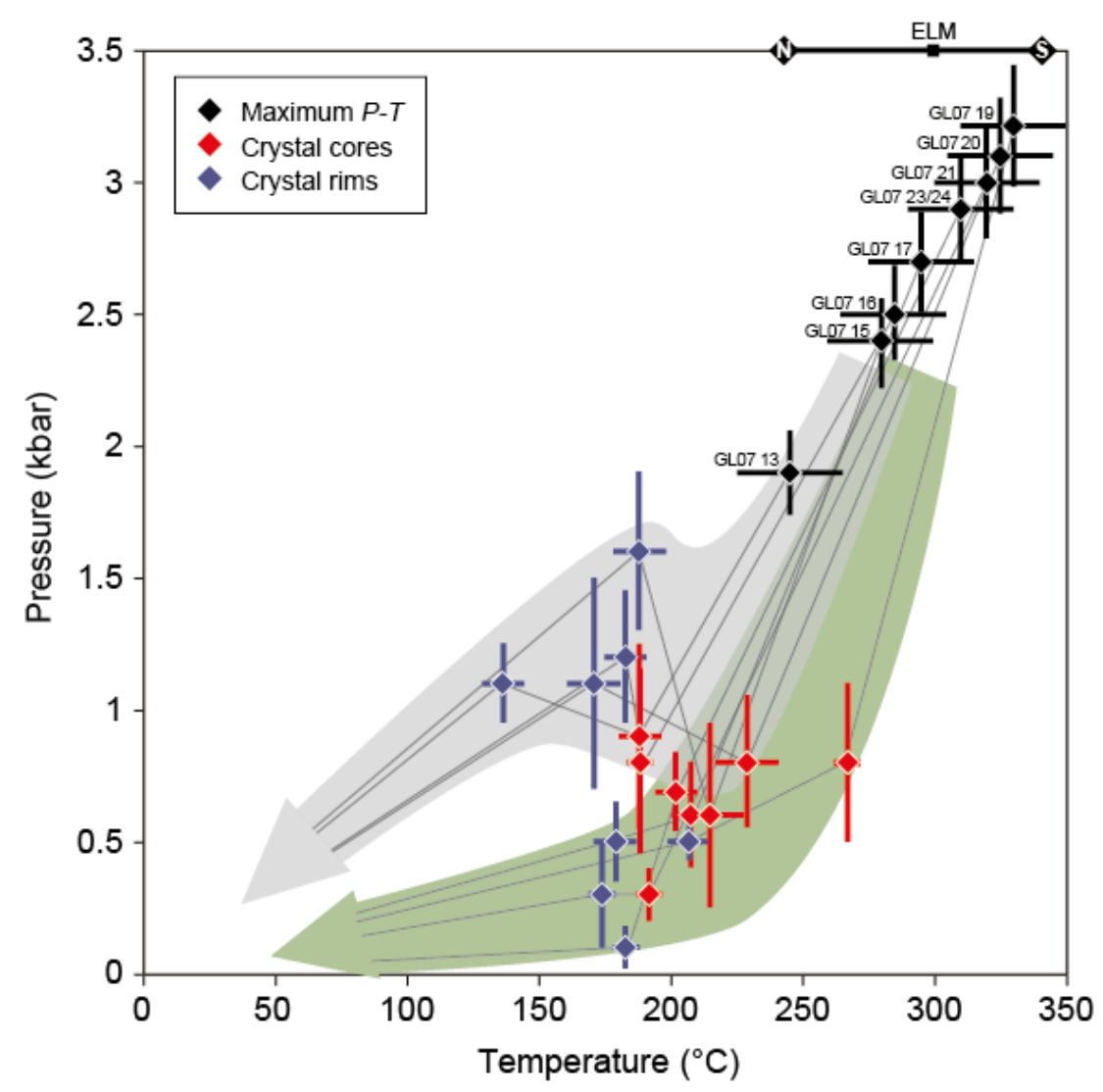

814

815 Fig. 5: Exhumation path drawn in a $P-T$ diagram by linking maximum $P-T$, chlorite-core and

816 chlorite-rim thermobarometry results for each sample. $P-T$ data from independent

817 conventional thermometers (in black), from combining Bourdelle et al. (2013a)/Lanari et al.

818 (2014) thermometers on chlorite crystal cores (in red), and combining Bourdelle et al.

819 (2013a)/Lanari et al. (2014) thermometers on chlorite crystal rims (in blue). Error bars on $T$

820 refer to uncertainty given by Ebert et al. (2007) (black points) and to standard deviation (red

821 and blue points). Error bars on $P$ refer to an assumed uncertainty of $\pm 10 \%$ (black points) and

822 to standard deviation (red and blue points). The N-S sampling profile is schematically

823 indicated at the top, on the basis of maximum $T$ and $P$.

824 

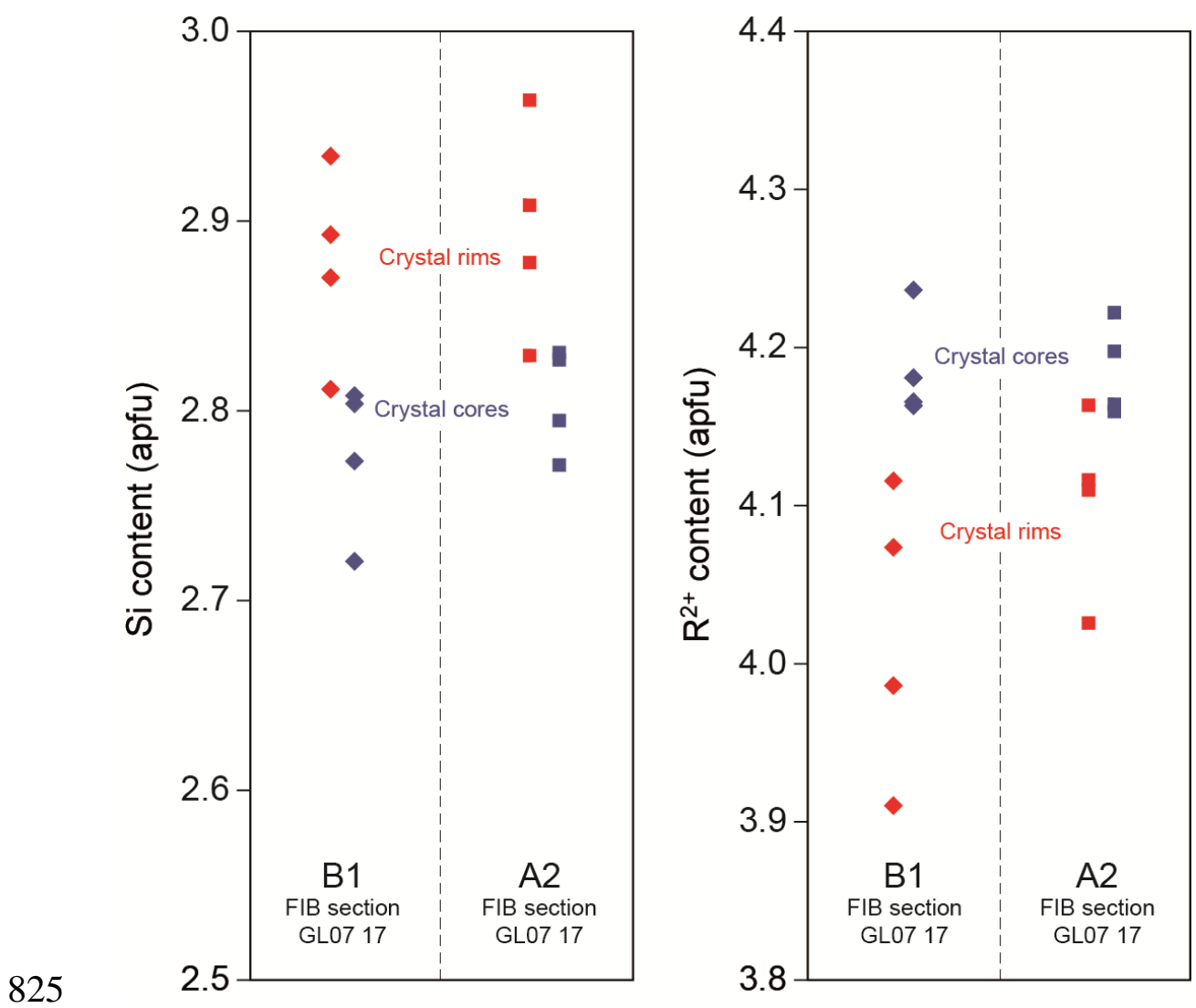

826 Fig. 6: Comparison of analyzed rim and core compositions of two chlorite grains (noted B1

827 and A2) from one sample (GL07 17). Compositions are represented by Si and $\mathrm{R}^{2+}$ contents (in

828 apfu). For clarity, we have considered only the four rim analyses and the four core analyses

829 per grain (i.e. for B1 and A2) that give the "extreme" $\log K$ (Eq. 3; see section 3.3).

830 


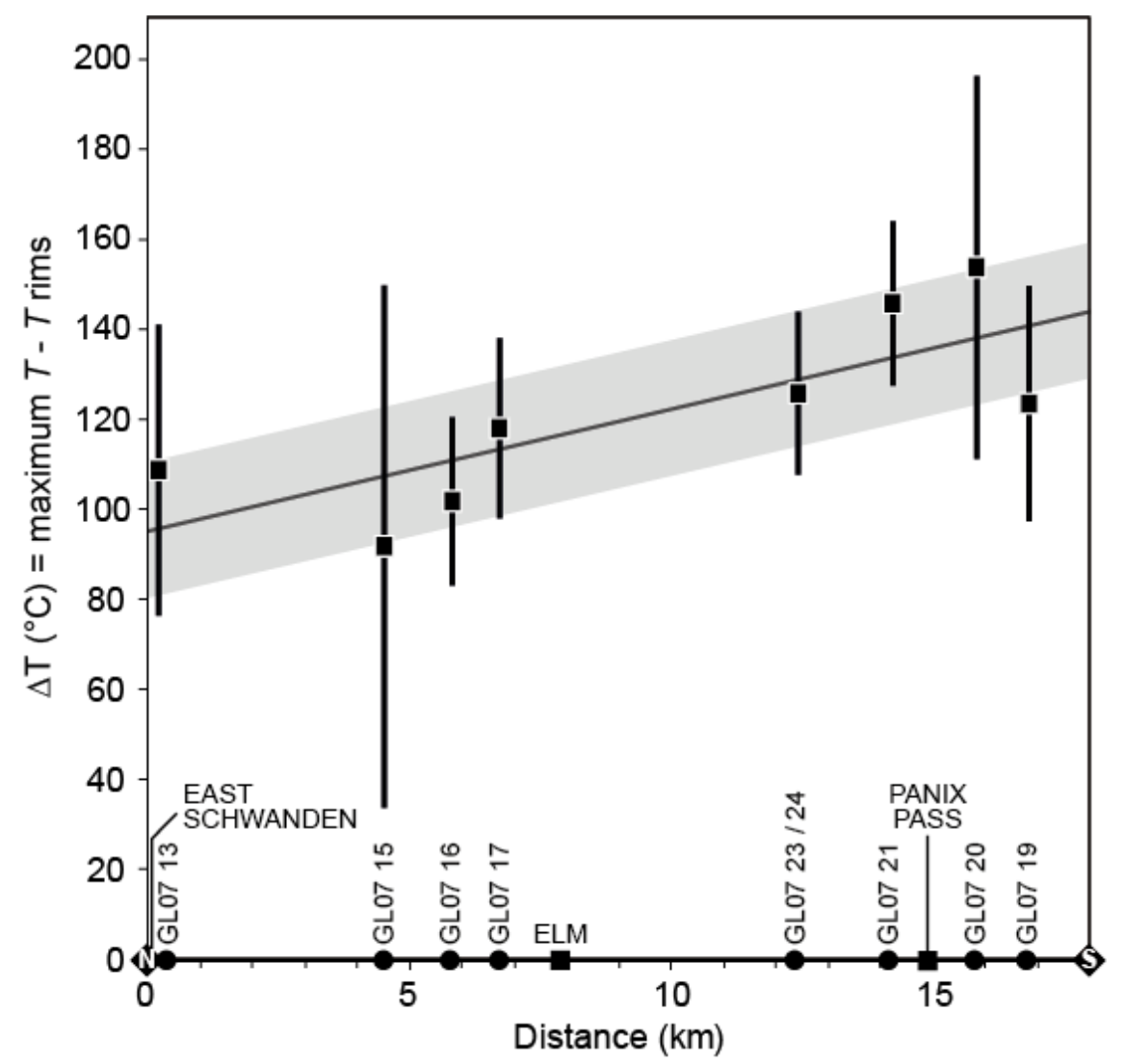

832 Fig. 7: Evolution of $\Delta T$ along the sampling profile (between East-Schwanden and Panix Pass).

833 For each sample, $\Delta T$ was calculated as the difference between maximum $T$ from the literature

834 and the average $T$ from chlorite rim thermometry (based on "extreme" compositions, see text;

835 Bourdelle et al. (2013a) thermometer). Error bars refer to the maximum of standard

836 deviations. Dark line: linear regression. Grey area: linear regression $\pm 15{ }^{\circ} \mathrm{C}$.

837 


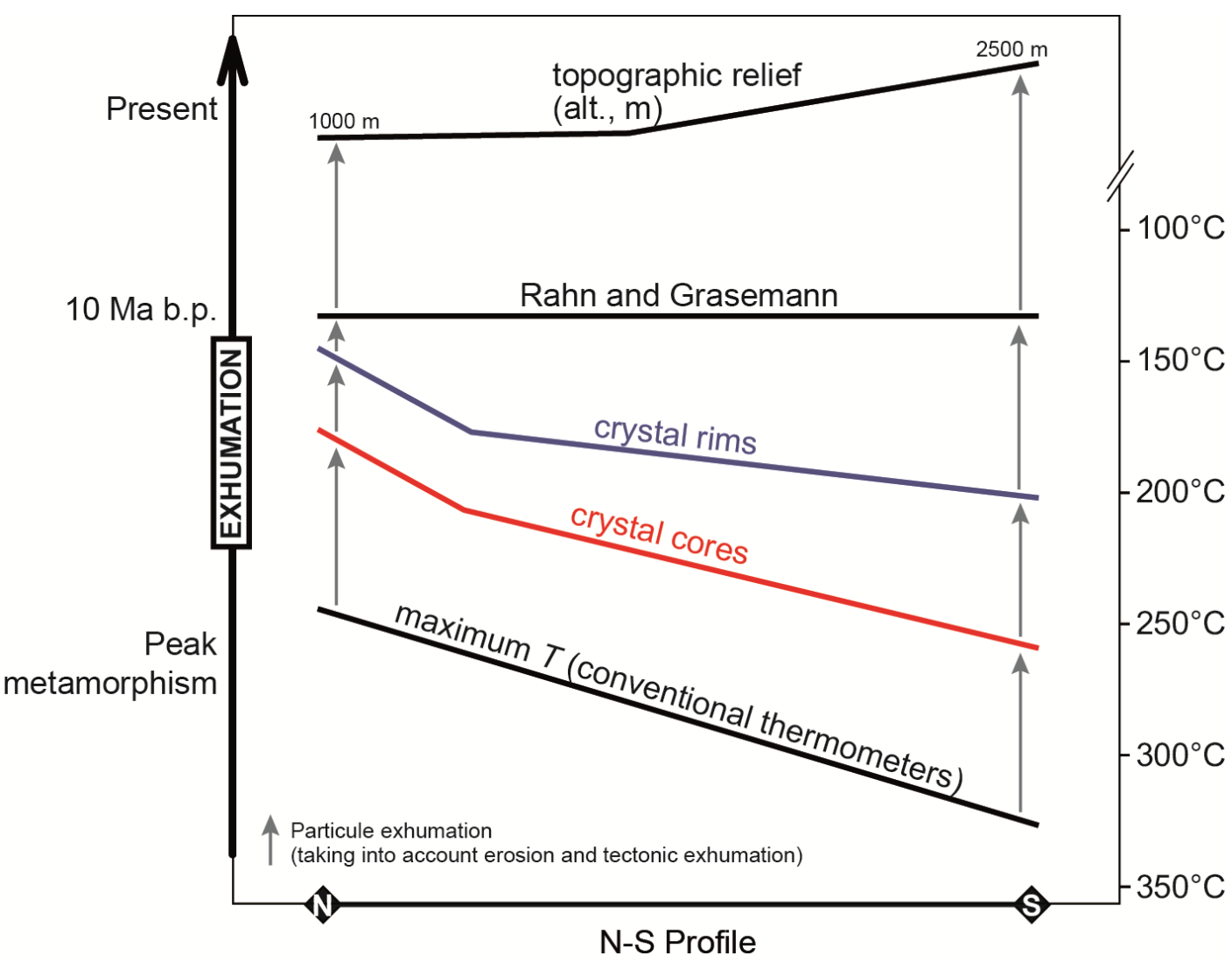

839 Fig. 8: Schematic exhumation scenario for the North-Helvetic flyschs along the studied

840 North-South profile, established from Rahn and Grasemann (1999; from fission track data and

841 numerical modelling) and the new thermobarometric data obtained from Glarus chlorites

842 (present study). Black, red and blue lines represent the relative rock burial at each exhumation

843 step, according to $T$. 